\title{
FISCAL DECENTRALIZATION, BUDGET DISCIPLINE, AND \\ LOCAL FINANCE REFORM IN RUSSIA'S REGIONS
}

\author{
by \\ Michael Alexeev, ${ }^{1}$ Nikolay Avxentyev, ${ }^{2}$ Arseny Mamedov, ${ }^{3}$ and Sergey G. Sinelnikov-Murylev ${ }^{4}$
}

July 2018

\begin{abstract}
Using a panel of Russian regions, we estimate the link between intraregional fiscal decentralization and regional budget deficits. Although Russia's regions are not as autonomous (either politically or fiscally) as regions in some other federal states, we obtain robust and statistically and economically significant results. Specifically, expenditure decentralization has a positive effect on consolidated regional budget balances, while transfer dependence of municipalities is associated with higher deficits. The impact of revenue decentralization depends on whether a regional government can use its tax revenue assignments with the same high degree of discretion that generally characterizes explicit fiscal transfers. We show that a 2009 local finance reform that limited the discretion of regional governments to assign regional tax revenue to municipalities has changed the effect of tax decentralization on budget discipline.
\end{abstract}

\footnotetext{
${ }^{1}$ Indiana University, Bloomington, Indiana, and the Russian Academy of National Economy and Public Administration, Moscow; e-mail: malexeev@indiana.edu.

${ }^{2}$ Financial Research Institute and the Russian Academy of National Economy and Public Administration, Moscow. ${ }^{3}$ Gaidar Institute for Economic Policy and the Russian Academy of National Economy and Public Administration, Moscow.

${ }^{4}$ Russian Foreign Trade Academy, Moscow.
} 


\section{FISCAL DECENTRALIZATION AND BUDGET DISCIPLINE IN RUSSIA'S REGIONS}

The recent financial crisis and the concomitant rise of budget deficits in a large number of countries have led to a significant expansion of the already substantial literature on the determinants of budget discipline and the consequences of fiscal imbalances. One important factor that has been conjectured to affect the extent of deficit spending is the degree of fiscal decentralization. In theory, fiscal decentralization produces an ambiguous effect on budget deficits. On one hand, fiscal decentralization, particularly if it is accompanied by political decentralization, could improve the oversight of the government by the population, including closer monitoring of expenditures. In other words, more fiscal autonomy typically imposes greater responsibility on local governments, so that local budget deficits cannot plausibly be blamed on inadequate funds from, and excessive expenditure requirements imposed by, the upper level of government. In addition, competition among lower levels of government for capital and labor may induce fiscal discipline by increasing the opportunity cost of expenditures (see Qian and Roland 1998). On the other hand, fiscal decentralization could result in local governments using their authority over expenditure decisions by committing to spend more than they take in -- if they (realistically) expect the upper level government to bail them out. That is, the "soft budget constraint" problem can be exacerbated in a multi-level decentralized federation (Breuille and Vigneault 2010). In addition, fiscal decentralization typically increases the number of veto players, generating a status quo bias. Although such a bias is usually taken as an impediment to fiscal consolidation (Rodden and Wibbles 2002, Schaltegger and Feld 2009), status quo bias can also provide a check to governmental and budgetary expansion. 
The consequences of fiscal decentralization have been tested mostly at the country level, i.e., looking at the degree of fiscal autonomy of the regions relative to the central government (see Baskaran 2010, Escolano et al. 2012, and several other papers briefly discussed below). ${ }^{5}$ The main disadvantage of this approach is that it is difficult to adequately take into account intercountry differences. Panel data methods can help account for time-invariant factors, but these approaches are not of much help in incorporating the effects of such hard-to-measure variables as macroeconomic policies, changing institutional arrangements, and other time-varying country specifics. Moreover, country-level data on the degree of revenue and expenditure decentralization can differ significantly depending on the source, raising serious questions about data reliability. For example, there are substantial differences between OECD and IMF/World Bank figures in the recorded shares of subnational revenues and expenditures for various countries. ${ }^{6}$

In part to alleviate the difficulties stated above, intraregional data have been used to evaluate the effects of fiscal decentralization on budget discipline, broadly understood (see, for example, Schaltegger and Feld 2009, and Freitag and Vatter 2011). ${ }^{7}$ Time-varying differences across

\footnotetext{
${ }^{5}$ The literature of the link between fiscal decentralization and budget consolidation is too large to be reviewed here. We briefly discuss only the most recent papers that are most relevant to our topic.

${ }^{6}$ For example, comparing World Bank and OECD data, we find that the former quotes the 2011 shares of subnational government expenditures in general government expenditures in Belgium, Finland, France, and Greece as, respectively, 33.05\%, 35.02\%, $18.67 \%$, and $5.53 \%$, while the OECD database shows $37.75 \%, 40.73 \%$, $20.02 \%$, and $5.58 \%$, respectively. Moreover, these differences change over time. Thus, according to the World Bank the subnational government expenditure share in Greece in 2010 was $5.10 \%$ while the OECD number is 7.16\%. The data are from http://web.worldbank.org/WBSITE/EXTERNAL/TOPICS/EXTPUBLICSECTORANDGOVERNANCE/0,,contentMDK:2311 2839 pagePK:148956 piPK:216618 theSitePK:286305,00.html and http://www.oecd.org/ctp/federalism/oecdfiscaldecentralisationdatabase.htm\#C 3 .

${ }^{7}$ Budget or fiscal discipline is a broad concept that can refer to the size or sustainability of public debt, annual budget deficits, or the speed of fiscal consolidation. We focus on annual budget deficits which are, of course, closely related to public debt and are less directly relevant to the issue of fiscal consolidation after a run-up in debt.
} 
regions within a single country are typically much smaller than those across different countries. For instance, all regions of a country are subject to the same macroeconomic policy of the central government. In addition, at least for some countries the data on regional budgets are much more reliable and consistent in terms of accounting methodology than are data collected for different countries.

The main goal of this paper is to use the data from Russian regions to estimate the link between intraregional fiscal decentralization and regional budget deficits. The important advantage of using Russian regional data is that the country has a relatively large number of regions and most (although not all) of the relevant fiscal data are publicly available. Also, as we show below (Section 1 and Table 1), there is a large variation within the relevant fiscal variables, both across regions and over time. One distinguishing feature of the Russian Federation is that the regions are not as autonomous in their fiscal policies as are, for instrance, Swiss cantons -- and thus the differences in Russian intraregional fiscal decentralization might not be expected to affect budget deficits in a consistent way. Nonetheless, using panel data for 2005-2013, we obtain rather robust and highly statistically and economically significant results. Most important, we show that expenditure decentralization tends to have a positive effect on the consolidated regional budget balance, particularly after the local finance reform that became effective in 2009. At the same time, conventionally measured revenue decentralization is associated with higher deficits; we show, however, that this outcome depends on the existing institutional arrangements, such as whether regional governments can use tax revenue assignments to municipalities in a highly discretionary manner, making them similar to transfers. 
In regressions covering the entire 2005-2013 period, conventionally defined tax decentralization is negatively and significantly associated with budget balance. However, if we consider separately decentralization of personal income tax (PIT) revenue and other tax revenues, only the former has a negative and consistently significant coefficient. The non-PIT decentralization measure, while retaining a negative coefficient, is either insignificant or only marginally significant, depending on the precise empirical specification. We argue that this difference between PIT and non-PIT decentralization is due to Russia's 2009 reform of local finances - a policy change that made it more difficult for regional governments to use non-PIT revenue assignments as discretionary transfers to particular municipalities. Indeed, we show that the relationship between non-PIT decentralization and regional budget deficits changed in 2009, while the effects of all other fiscal decentralization measures on budget deficits remained consistent across the entire 2005-2013 period. We consider this result as evidence that the 2009 reform was at least partially successful in reducing the ability of the regional governments to use non-PIT tax assignments in a discretionary manner, and this reduced discretion helped to lower regional budget deficits.

Also, we find that increased dependence of municipal budgets on transfers from the regional government leads to higher deficits of consolidated regional budget -- supporting the "soft budget constraints" logic. This finding is consistent with the results in the related literature such as Eyraud and Lusinyan (2013) and Eyraud and Badia (2013), although these articles address center-region budgetary relations while we focus on intraregional budgets. In short, we show that expenditure decentralization unambiguously results in lower regional deficits, while increased transfers lead to greater deficits. Therefore, one way to improve budget discipline in 
subnational units would be to increase expenditure decentralization. However, in order to achieve greater expenditure decentralization, a regional government would have to either increase explicit transfers to its municipalities or assign additional tax revenues to municipal budgets. Given our estimation results, the main policy implication is that the combined effect of increasing expenditure decentralization via greater explicit transfers tends to increase budget deficits whereas such expenditure decentralization undertaken via additional tax assignments reduces budget deficits in a typical region, particularly if these tax assignments leave little room for discretionary redistribution by regional authorities.

We conjecture that the deficit-reducing role of expenditure decentralization in Russia's regions most likely takes place because municipalities possess harder budget constraints than does the regional government. ${ }^{8}$ Harder municipal budget constraints imply that the regional government finds it easier to precommit to a given level of expenditures when those expenditures are allocated to the municipalities. A transfer of funds from the regional budget to municipalities, particularly if made via grants of fixed amounts, may work similarly to block granting of federal aid to the states in the US - a mechanism that is viewed by its proponents as a device to limit federal expenditures (see Dilger and Boyd 2014). Of course, this approach would work in Russia only if the regional governors are actually interested in budget discipline. We argue below that

\footnotetext{
${ }^{8}$ For example, most municipalities cannot count on a bailout by the federal government. Also, although commercial loans constitute a large share of municipal borrowings, only relatively few financially stable municipalities can borrow significant amounts. Thus, in the Altai krai region, three of the largest cities account for about $90 \%$ of all municipal commercial debt while their combined shares of consolidated municipal budget revenues and expenditures are under $40 \%$. In the Kaliningrad region, the capital holds $98 \%$ of all municipal commercial debt while accounting for under $60 \%$ of municipal budgets. Although we do not have borrowing data for most Russian regions, we expect that these are rather typical examples.
} 
the governors and even the local authorities do indeed have some incentives to keep budget deficits in check, despite their limited accountability to the citizens.

The empirical literature on the link between fiscal decentralization and budget deficits has produced contradictory results. Our findings are in line with some of the papers but differ from others. It is, however, somewhat surprising that we obtained any significant results, given the high degree of political and fiscal centralization in Russia. ${ }^{9}$ Two articles mentioned earlier, Schaltegger and Feld (2009) and Freitag and Vatter (2011), use data on Swiss cantons to show some qualified support for the positive influence of decentralization on regional budget balances, although neither article focuses on regional budget deficits per se. Schaltegger and Feld (2009) find that fiscal decentralization increases the likelihood of a successful fiscal consolidation, while the likelihood is reduced by coalition governments and large parliaments. Freitag and Vatter (2011) distinguish between prosperous times and recessions and show that decentralization affects changes in regional government debt only in "economically poor times," when decentralized cantons exhibit stronger budget discipline. Moreover, they find that for regional budget discipline, political decentralization is just as important as revenue decentralization, while administrative decentralization (i.e., the number of local administrations) is even more important. To some extent, our results contradict this last finding by showing that fiscal decentralization matters even in a politically centralized environment,

\footnotetext{
${ }^{9}$ Unlike several other federations such as US, Switzerland, or India, the Russian Federation is highly centralized politically and Russian regions appear to have little fiscal independence. The consequences of Russia's political centralization for fiscal federalism are analyzed by Blanchard and Shleifer (2001) and Treisman (2000). The degree of fiscal independence of Russia's regions is examined by Plekhanov (2004) and Alexeev and Weber (2013). Zhuravskaya (2000), Alexeev and Kulyandskaya (2003), and Shishkin (2013) study the fiscal independence of municipalities within Russia's regions.
} 
where the differences in the degree of political decentralization across regions are minor. ${ }^{10}$ Our results are also at some variance with Riker's (1964) statement that subordination of regional authorities to the federal center undermines the benefits of fiscal decentralization. ${ }^{11}$ Thus our second policy implication is that fiscal decentralization can be helpful in improving budget discipline even in politically centralized countries.

As mentioned earlier, most empirical work on the link between fiscal decentralization and budget discipline focuses on center-region fiscal relations rather than intraregional decentralization. Using panel data for 37 countries during 1986-1996, Rodden (2002), for instance, finds that "as countries increase their reliance on intergovernmental transfers over time, subnational and overall fiscal performance decline". Among more recent studies, Neyapti (2010) uses a large unbalanced panel of countries to show that both expenditure and revenue decentralization are associated with lower fiscal deficits; alternatively, based on a panel of 19 OECD countries, Thornton (2009) shows that "properly measured" revenue decentralization does not have a statistically significant impact on general government balances. ${ }^{12}$ In partial contrast to Thornton (2009), Presbitero et al. (2014) demonstrate that greater reliance on property taxes by subnational governments promotes fiscal discipline (as measured by the ratio or primary balances to GDP). Baskaran (2010) examines a panel of 17 OECD countries for 1975-

\footnotetext{
${ }^{10}$ We did not control for the number of municipal administrations, but controlling for region's population can probably serve as a good proxy. Also, unlike Freitag and Vatter (2011), we examine the effect of fiscal decentralization on budget deficits rather than on debt. However, debt obviously arises from annual deficits and thus these two measures are closely linked.

${ }^{11}$ We do not wish to take this difference from Riker's thesis too far, because it is not entirely clear whether the reduction of regional budget deficits is a benefit to the regional constituencies or to the federal government. We also note that Riker's theory was supported empirically by Enikolopov and Zhuravskaya (2007).

12 Unlike some other authors, Thornton's (2009) measure of fiscal decentralization includes only the revenues over which the subnational government has full autonomy.
} 
2001 and finds that expenditure decentralization reduces public debt (and thus presumably deficits) while tax decentralization and transfers do not have a statistically significant effect. Asatryan et al. (2015), on the other hand, find a positive effect of revenue decentralization on budget discipline in a panel of 23 OECD countries for 1975-2000, and for 34 OECD countries for 2002-2008. Foremny (2014) examines the effect of tax autonomy rather than tax decentralization and also finds that such autonomy reduces subnational deficits in a panel of 15 EU countries over the period of 1995-2008.

Escolano et al. (2012), whose econometric specifications are closest to ours, use a panel of 27 European countries and conclude that only expenditure decentralization improves government fiscal discipline; revenue decentralization has the opposite effect. While Escolano et al. (2012) do not present a compelling explanation for the latter result, we show that the negative effect of tax decentralization on budget discipline could be due to the use of tax revenue assignments as discretionary transfers.

In general, our findings suggest that fiscal decentralization can improve budget balances in a broader range of environments than have been identified so far.

The rest of the paper is organized as follows. In the next section we briefly explain the relevant features of Russia's fiscal federalism arrangements. Section 2 is devoted to data description. Econometric specifications, estimation techniques, and main results are discussed in Section 3. Section 4 concludes. 


\section{FISCAL FEDERALISM IN RUSSIA}

During the period covered by our data the Russian Federation consisted of more than 80 "Subjects of the Federation" or regions subdivided into municipalities. Most of the regions are referred to as provinces (oblasts), but there are also "republics", krais, autonomous districts (okrugs), and two federal cities, Moscow and St. Petersburg. Regions have their own governors and parliaments, but their political independence is rather limited. Fiscally, Russia is also one of the more centralized federal countries in the world, particularly on the revenue side. All taxes are collected by the federal tax service, which then channels tax revenues into the budgets of the appropriate level of government. By law, taxes in Russia are classified into federal, regional, and municipal, depending on what level of government determines the base and the rates, although it is important to note that federal legislation imposes limits on the ability of lower levels of government to modify the base and the rates of "their" taxes. ${ }^{13}$ All revenue from regional taxes goes into regional or municipal budgets, but some of the revenue from federal taxes accrues to the budgets of the lower levels of government. The classification of taxes, the rules with respect to rate and base determination by various levels of government, and expenditure responsibilities are contained in Russia's Tax Code, Budget Code, and certain other federal laws.

Despite a relatively high degree of political centralization within the Russian Federation and the uniformity of the framework of tax and budget legislation, there is a great deal of diversity in

\footnotetext{
${ }^{13}$ Although corporate income tax is classified as "federal", regional governments get most of revenue from it and can lower its rate by up to 4.5 percentage points. In some special circumstances, the rate could be lowered even further.
} 
the degree of fiscal decentralization, both across Russia's regions and over time. This is particularly true with respect to expenditure decentralization. ${ }^{14}$ The coefficient of variation of our measure of expenditure decentralization across regions in our sample has fluctuated between 0.204 in 2006 and 0.269 in 2010 (the means and standard deviations of our variables across regions are shown in Table 1). There was also significant variability in expenditure decentralization within regions over time, with most regional coefficients of variation over nine years ranging between 0.1 and 0.3 . For comparison, the coefficient of variation of expenditure decentralization across states in the US has fluctuated between 0.172 and 0.188 during 19972013. Also, the coefficients of variation of expenditure decentralization within each state during the same period have ranged between 0.015 and $0.083 .{ }^{15}$ The average coefficient of variation of the transfer dependence of municipalities within Russia's regions was 0.1 , with most of the regional coefficients of variation being between 0.04 and 0.16 . This compares with the coefficient of variation for transfer dependence of the US municipalities within states of about 0.08 .

\footnotetext{
${ }^{14}$ We note that Russian regions and municipalities generally have considerably more discretion with respect to their expenditures (excluding subventions) than with respect to their revenues. For example, even in the area of primary and pre-school education - which is relatively highly regulated by the federal government and is funded largely via transfers from regional budgets - municipal authorities typically can redistribute budgetary resources among their schools and kindergartens. It is also important to keep in mind that the degree of municipal spending autonomy differs substantially across regions. For example, the Perm region is characterized by substantial spending autonomy of its constituent municipalities, while municipalities in Vologda oblast enjoy lower autonomy. Nonetheless, municipalities have some spending autonomy in all regions, at least on the margin. Also, it is difficult to formalize and measure differences in spending autonomy of municipalities across all of Russia's regions and for all years in our sample, and thus we could not account for such differences.

${ }^{15}$ The calculations for the US are based on data from U.S. Census Bureau, Annual Surveys of State and Local Government Finances (https://www.census.gov/govs/local/historical data.html). The numbers reflect "direct expenditures", i.e., expenditures of state-owned or municipal-owned utilities, liquor stores, and insurance trusts are excluded.
} 
During the period of our study, Russian federal tax revenues, including revenues from foreign trade (all of which accrue to the federal government), were significantly greater than the tax revenues of sub-national governments. This situation is, of course, fairly common in federations. For most Russian regions, revenues are not sufficient to cover regional budget expenditures and the difference is made up by various types of transfers from the federal budget. For our purposes, it is most important to distinguish between three types of transfers: grants aimed explicitly at balancing the regional budget (dotatsii na sbalansirovannost', which we will refer to as balancing grants), ${ }^{16}$ "subventions" (i.e., transfers from the upper level of government that have a precisely prescribed use), ${ }^{17}$ and all other transfers.

Regional governments also typically make transfers to municipal budgets, including subventions and other types of transfers. In addition, regional governments have the flexibility to assign shares of regional revenues from either regional or federal taxes to municipal budgets. These tax share assignments can be either the same ("uniform") for all municipalities within the region or they can be differentiated. During 2006-2008, the Russian Federation underwent a period of gradual transition to a different set of intraregional fiscal rules, particularly those related to municipalities. The most important change for our purposes became mandatory as of January 1, 2009, and most regions did not implement it until then. Namely, prior to 2009, regions could assign differentiated shares of any regional tax or regional portion of a federal tax

\footnotetext{
${ }^{16}$ There are also "dotatsii na biudzhetnoe vyravnivanie" or equalization transfers. We include them in "other transfers" because they are not dependent on the actions of regional governments in the short or even the medium term.

${ }^{17}$ For example, one of the largest categories of subventions is the subvention for unemployment compensation. This is a federal expenditure, but the actual payments are made by regional employment services located in municipalities. In essence, subventions represent expenditures by the upper level of government that are simply administered by the lower government level, without any room for reallocating the funds to other purposes.
} 
to municipalities. In practice, differentiated assignments by law served as substitutes for equalization transfers. Starting in 2009 , the regions were required to use uniform assignment shares for all regional taxes except the personal income tax, for which either uniform or differentiated assignments can be made. As we will demonstrate, this change resulted in important distinctions between the roles played by assignments of different types of taxes.

\section{DATA}

We focus on the relationships between the regional government and its municipalities. Therefore, we exclude from consideration the "federal cities" of Moscow and St. Petersburg, because the relationship between federal city governments and their "municipalities" is quite different from that in all other regions. ${ }^{18}$ In addition, we exclude Moscow oblast, because a large part of it was ceded to the city of Moscow in 2012, making the data for 2005-2011 not comparable to the 2012-2013 numbers. We also exclude the republics of Ingushetia and Chechnya. The data for these republics are extremely unreliable. For instance, the primary budget balance as a percentage of budget revenue in Ingushetia ranged from 23\% in 2011 to negative $120 \%$ in 2013. In Chechnya, this same indicator - crucial for our analysis - ranged from $8 \%$ in 2012 to negative $143 \%$ in 2009 . No other republic or oblast comes anywhere close in terms of budget balance variability. Our benchmark regressions also exclude Tyumen' and Arkhangelsk oblasts; these oblasts contain regional entities (okrugs) that have the status of autonomous subjects of the Russian Federation, while at the same time are formally included in the surrounding oblast. This situation obviously makes the intraregional fiscal and

\footnotetext{
${ }^{18}$ For example, these federal cities are exempt from at least one important provision of the Budget Code (Art. 58) regulating allocation of regional revenues between regional and municipal budgets.
} 
administrative relationships quite different from other regions. ${ }^{19}$ Moreover, Tyumen' oblast is Russia's main oil producer. Because of the changes in the allocation of tax revenue from oil, along with the considerable volatility of oil prices, Tyumen's finances are also quite different from other regions; for instance, the Tyumen' budget balance displays significantly larger variation than most regions in our dataset. (Not surprisingly, when we include in our estimations these unusual regoins - unusual from the point of view of intraregional fiscal relations - the statistical significance of the relevant coefficients is reduced, although our main results still hold.) Finally, we also exclude the Chukotka okrug. This okrug is very sparsely populated and its budget was to a large extent determined by billionaire Roman Abramovich, who served as its governor during 2001-2008 and then as Chairman of its regional parliament in 2008-2013. In addition, Chukotka's primary budget balance as a share of budget revenue varied from $46 \%$ to negative $71 \%$ during $2009-2013$, which is much more volatile than in all other regions except Chechnya and Ingushetia. After all the exclusions stated above and accounting for some missing data, we end up with an unbalanced panel dataset containing observations on 72 regions for nine years, with a total of 576 observations.

Our dependent variables are consolidated regional budget balance and consolidated primary budget balance in a given year. ${ }^{20}$ We measure budget balance relative either to total budget revenue (excluding transfers) or to the gross regional product (GRP). When we calculate budget balances, we take out balancing grants. This is because we are interested in the amount of the

\footnotetext{
${ }^{19}$ The degree of independence of these okrugs from their oblast differs. The two okrugs belonging to Tyumen' oblast are virtually fully fiscally independent (although they make large transfers to the oblast budget) while the okrug in Arkhangelsk oblast has a fairly limited degree of autonomy.

${ }^{20}$ By "consolidated" we mean combined regional and municipal budgets.
} 
deficit that has something to do with the actions of the regional government and not with the ways the regional government finances the deficit. We note, however, that in terms of signs and statistical significance the results based on budget balances not adjusted for balancing grants are very similar to the ones presented below. We prefer the specification with primary balance as the dependent variable, because interest payments on the stock of pre-existing debt are largely independent of the current actions of the regional government. We use overall budget balance as a dependent variable in one of our robustness checks and show that our results still hold.

Our three main fiscal independent variables are (1) "expenditure decentralization" calculated as the share of sub-regional (municipal) expenditures in total budget expenditures in the region; (2) "tax revenue share of municipalities" - the share of tax revenue accrued to municipalities in total tax revenue; and (3) "transfer dependence" - the ratio of transfers from the regional government to municipalities in total municipal revenues (including the transfers). In calculating expenditure decentralization and transfer dependence measures, we exclude subventions: as we noted earlier, subventions typically do not involve almost any expenditure flexibility on the part of the receiving government.

Specifically, we calculate expenditure decentralization according to the following formula:

$$
\text { ExpDec }=\left(1-\frac{\operatorname{RegExp}-\text { Trans }+ \text { MSubven }}{\text { ConsExp }- \text { RSubven }}\right) \times 100
$$

where RegExp represents all expenditures of the regional government, Trans are transfers from the regional budget to municipalities, MSubven stands for the part of Trans that are 
"subventions" (i.e., the component of transfers to municipalities over which municipalities have virtually no control), ConsExp denotes overall expenditure of the consolidated budget, and RSubven denotes all subventions that show up on the revenue side of the consolidated regional budget.

Municipal revenue share (MuniRevShare) is the share of municipal tax revenue in total tax revenue of the consolidated budget. Although one may view this measure as "tax decentralization", we argue that it does not necessarily reflect the degree of revenue independence of municipalities from the regional government. As we noted earlier, tax share assignments made at the discretion of regional governments have been used mainly as a substitute for transfers to cover imbalances in municipal budgets. This implies that there is little substantive difference between transfers and the shares of regional taxes allocated to municipalities - at least to the extent that these tax share allocations (tax assignments) are made in a discretionary manner, i.e., as long as the regional government is free to assign differentiated tax shares to different municipalities. ${ }^{21}$ As stated earlier, regional governments possessed such discretion with respect to all their tax revenues prior to 2009, but have retained this discretion only with respect to PIT revenues since then. Our results presented below are consistent with the view that tax assignments act as transfers when the regional governments possess discretion in allocating their tax revenues to municipalities.

\footnotetext{
${ }^{21}$ Strictly speaking, even prior to 2009 regional governments were required to keep the same tax assignments for at least three years, thus in theory limiting regional government discretion. However, this constraint was not meaningful in practice, because regional 3-year budgets could be changed every year and tax assignments could be changed together with the revised 3-year budget.
} 
Because of the differences between PIT and other regional tax revenues discussed above, we also use two variables (MuniPITShare and MuniOthShare) that decompose municipal revenue share into municipal share of PIT revenues and municipal share of other taxes. ${ }^{22}$ PIT sharing can be viewed mainly as an implicit transfer made at the discretion of regional governments. Other tax revenue sharing can be treated the same way prior to 2009 , but not after that year, because of the uniform assignment rule for non-PIT tax revenue shares. The 20009 reform presumably makes the assignment of other tax revenues less dependent on the specific fiscal situation within a municipality and, therefore, less likely to be viewed as discretionary with respect to a given municipality and, therefore, less likely to generate soft budget constraints.

The transfer dependence variable (TransDep) is calculated as the share of explicit transfers from the regional government in municipal budget revenues, without counting subventions. The consolidated debt variable $(D e b t)$ is the share of all types of debt of both regional and municipal governments in the total budget revenue (excluding transfers) of the consolidated regional budget. The consolidated debt does not include loan guarantees issued by either regional or municipal governments; it also excludes intraregional budget loans. The descriptions and sources for all our variables are presented in Table 1. Descriptive statistics and pairwise correlations among the variables are shown in Tables 2 and 3, respectively.

We interpret our expenditure decentralization measure as a proxy for fiscal decentralization, while transfer dependence reflects fiscal centralization. The interpretation of MuniRevShare

\footnotetext{
22 PIT revenues comprise on average about two thirds of all municipal tax revenues in our data.
} 
depends on the type of revenue (PIT vs. other tax revenue) and the time period (prior to 2009 or later). Note that both the range and the standard deviation of these fiscal (de)centralization variables are fairly sizable.

\section{ESTIMATION APPROACH AND MAIN RESULTS}

Our first specification is the following fixed effects regression:

$$
B_{i t}=b_{1} \text { ExpDec }_{i t}+b_{2} \text { MuniRevShare }_{i t}+b_{3} \text { TransDep }_{i t}+b_{4} \text { Debt }_{i t-1}+c X_{i t}+\gamma_{i}+\mu_{t}+\varepsilon_{i t}
$$

where regions and years are indexed by $i$ and $t$, respectively, $B$ represents a measure of regional budget balance, $X_{i t}$ is a vector of non-fiscal control variables, $\gamma_{i}$ and $\mu_{t}$ denote region and year fixed effects, ${ }^{23}$ respectively, and $\varepsilon_{i t}$ is the error term. All standard errors are robust and are clustered by region. As noted earlier, we also estimate regressions where we replace

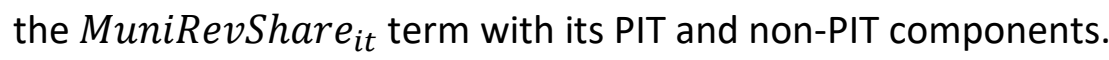

Note that municipal revenue share and transfer dependence are not collinear with the the degree of expenditure decentralization. Substantively, this is because municipal budgets can incur surpluses or deficits that could be covered by borrowing. In addition, transfer dependence is calculated relative to municipal revenue (including transfers and other non-tax municipal revenues) while municipal tax revenue share is calculated relative to consolidated tax revenue and expenditure decentralization is calculated relative to the total expenditures of the consolidated budget. In fact, an OLS regression of expenditure decentralization on municipal revenue share and transfer dependence using pooled data for all years results in an R-squared

\footnotetext{
${ }^{23}$ We note that Hausman test strongly rejects random effects specification.
} 
of less than 0.07 . Nonetheless, as a robustness check, we also report the results of specifications that exclude either one or two of our three main measures of fiscal decentralization (see Appendix).

The vector of non-fiscal controls, $X_{i t}$, in regression (2) includes a measure of region's dependence on natural resources (share of mining in GRP), GRP growth rate, logarithm of region's population, and lagged logarithm of real per capita GRP. These are fairly conventional variables that might affect regional revenue raising capacity and expenditure responsibilities. ${ }^{24}$

It is possible that our fiscal variables and the GRP growth rate are endogenous with respect to budget balance. Because we do not have natural external instruments for these variables, we instrument them using the system-GMM dynamic panel estimation approach developed by Arellano and Bover (1995) and Blundell and Bond (1998). This method is designed specifically for panels with potentially endogenous right-hand side variables, i.e., variables that may be correlated with past or current realizations of the error term. Moreover, this approach also addresses fixed effects, heteroscedasticity, and autocorrelation within groups (regions in our case), and allows for the inclusion of the lagged dependent variable on the right hand side of the regression. To the extent that there is genuine inertia in regional budgeting, e.g., due to budgeting "from the achieved level" (the so-called "ratchet principle"), the inclusion of the lagged dependent variable among the regressors may improve the estimates. However, to the extent that budgeting in the current year is not based on last year's numbers, the inclusion of a lagged dependent variable leads to a downward bias in estimates of the coefficients of the

\footnotetext{
${ }^{24}$ We also ran regressions with other independent variables, e.g., share of urban population and regional Gini coefficients. The results were qualitatively the same. These results are available upon request.
} 
other variables. Although system-GMM is not a perfect substitute for valid external

instruments, it does work reasonably well as long as all the relevant tests of instrument validity are satisfied and the number of instruments is kept sufficiently low relative to the number of groups (regions). ${ }^{25}$ Also, the validity of estimates is enhanced when the results of fixed effects (within estimator) regressions are consistent with those of system-GMM.

We have considered four different measures of budget balance (ratios of either primary or total budget balance to either total budget revenue excluding transfers or to GRP) but as we show later, the results based on primary balance and overall balance as well as the results based on the ratio of budget balance to budget revenue and to GRP are qualitatively very similar. In our benchmark regressions we use only the ratio of primary balance to total budget revenue (excluding intraregional transfers). This is because the ability to cover deficits depends mainly on the size of the budget revenue, although one could argue that the regional authorities have some flexibility to change tax and other revenue collections as a share of GRP. ${ }^{26}$

The fixed effects and system GMM estimates of (2) are shown in Table 4. First, note that the coefficients of expenditure decentralization are positive and statistically significant in all regressions. The coefficients of transfer dependence are always negative and highly statistically significant in all specifications. But the most interesting result has to do with the coefficients of municipal revenue shares. When we use municipal revenue share based on all taxes, its

\footnotetext{
${ }^{25}$ In order to avoid instruments proliferation, we use the "collapse" option of the xtabond2 procedure in Stata as suggested by Roodman (2009).

${ }^{26}$ This flexibility is rather limited, however. As noted earlier, regions are allowed to lower their profits tax rate by up to 4.5 percentage points, but they are not allowed to modify either the rate or the base of their most important source of revenue: the personal income tax. Moreover, all taxes in Russia are collected by the federal tax service that is, at least formally, completely independent from the regional government.
} 
coefficient is negative and significant at the $1 \%$ level (see columns 1 and 3 ). However, when we split revenue shares into the municipal share of PIT and the municipal share of other taxes, the coefficient of the latter loses statistical significance in the system-GMM regression and is significant only at the $10 \%$ level in the OLS FE specification, while the coefficient of the PIT share remains significant in both regressions (see columns 2 and 4). We argue that this result is due to the regime change that took place starting in 2009 when the regional governments lost a substantial degree of discretion with respect to the assignment of non-PIT revenues to municipalities: essentially, non-PIT tax assignments could no longer be used as transfers.

As an initial test of this conjecture, we add to our regressions the interactive terms between our main fiscal variables and a dummy variable which equals zero for years 2005-2008 and is set to unity for the post-2008 period. The coefficients of these interaction terms reflect the change in the relationship between these fiscal variables and the dependent variable starting in 2009. ${ }^{27}$ The results presented in Table 5 support our argument. The coefficients of the interactive terms involving the municipal revenue share of non-PIT taxes (columns 2 and 4) have the opposite signs from the corresponding direct terms and are close in absolute value to the direct terms, while the coefficients of the interactive terms involving PIT have the same negative sign as the corresponding direct coefficients, although they are not statistically significant.

The coefficients of accumulated debt, mining share in GRP, and lagged per capita GRP do not exhibit consistent statistical significance, particularly in system-GMM regressions. One

\footnotetext{
${ }^{27}$ Note that because all our regressions contain dummy variables for years, there is no need to include the post2008 dummy variable itself in the regressions.
} 
explanation for the lack of statistical significance of the consolidated debt measure could be that accumulated regional debt might have at least two effects on budget balance that act in opposite directions. On one hand, debt can be an indication of fiscal problems in the region that negatively affect budget balance; on the other hand, accumulated debt could make regional authorities more fiscally conservative than they otherwise would have been. Moreover, for most regions debt was relatively small during the period of our study and thus this variable can be quite noisy.

Not surprisingly, the lagged dependent variable in system-GMM regressions has a positive and statistically significant coefficient, pointing to a degree of inertia in regional budget balances. However, this coefficient is considerably less than unity, suggesting that the inertia is not strong.

If there was a regime change with respect to the role of non-PIT tax assignments starting in 2009, we would expect a sharper relationship between our measures of fiscal decentralization and regional budget balances during 2009-2013 relative to the entire $2005-2013$ period. As Table 6 demonstrates, this is indeed the case. Expenditure decentralization and the municipal share of PIT are now statistically significant at (or very close to) the $1 \%$ level in all specifications, while transfer dependence remains significant at $1 \%$. The municipal share of non-PIT revenue is statistically insignificant. Moreover, the point estimates of the coefficients of the municipal share of PIT and of transfer dependence are remarkably close. Given that the average values of these variables for 2009-2013 are also quite close, this serves as another argument for treating the (marginal) assignments of PIT revenues to municipalities as transfers. It is also important to 
note that system-GMM point estimates are not much different from point estimates obtained in the fixed effects specifications. This is reassuring and suggests that neither endogeneity nor the dynamic nature of the panel are likely to bias our estimates significantly.

Nonetheless, we consider system-GMM estimates more reliable than fixed effects ones. Using the system-GMM point estimates in column 3 of Table 6 , we now evaluate the combined effect of increasing expenditure decentralization through increasing transfers to municipalities and via increasing tax assignments to municipalities. That is, we calculate the estimated change (in rubles) in the consolidated regional deficit of an "average" region as a result of increasing both municipal expenditures and transfers or both municipal expenditures and tax assignments to municipalities by one ruble. The results are presented in the table below: ${ }^{28}$

\begin{tabular}{|l|c|c|c|c|c|}
\hline \multicolumn{1}{|r|}{ Year: } & 2009 & 2010 & 2011 & 2012 & 2013 \\
\hline $\begin{array}{l}\Delta \text { budget balance when } \\
\text { expenditures are increased } \\
\text { by 1 ruble via transfer }\end{array}$ & $-0,294$ & $-0,335$ & $-0,310$ & $-0,450$ & $-0,399$ \\
\hline $\begin{array}{l}\Delta \text { budget balance when } \\
\text { expenditures are increased } \\
\text { by 1 ruble via tax assignments }\end{array}$ & 0,586 & 0,719 & 0,761 & 0,840 & 0,788 \\
\hline Mean ExpDec & 32.70 & 30.38 & 31.98 & 29.56 & 30.81 \\
\hline Mean MuniRevShare & 27.50 & 25.46 & 24.15 & 22.64 & 23.71 \\
\hline Mean TransDep & 42.99 & 41.74 & 43.84 & 42.45 & 43.40 \\
\hline
\end{tabular}

According to the above table, increasing expenditure decentralization via greater transfers to municipalities would lead to higher budget deficits (lower budget balance), while the opposite

\footnotetext{
${ }^{28}$ Budget deficits estimates were obtained using coefficients from column 3 of Table 6 and applying them to fiscal variables calculated as ratios of the averages of the respective numerators and denominators for each year. Note that when expenditure decentralization is increased via an increase in transfers, the overall expenditure of the regional budget doesn't change, because an increase in transfers to municipalities is offset by a decrease in direct expenditures of the regional budget. At the municipal level, expenditures increase as does dependence on transfers. When municipal expenditures increase as a result of increased municipal revenue share, both regional budget expenditures and municipal transfer dependence decline.
} 
result obtains when municipal expenditures are increased by assigning greater shares of regional taxes to municipalities. This result has the obvious policy implications. Moreover, based on the results in column 4 of Table 6 discussed above, additional tax assignments to municipalities would be particularly beneficial with respect to reducing deficits if these assignments are made under a system involving limited or no discretion for the regional government. Recall that the estimates of the effect of those tax assignments on consolidated budget deficits are not statistically significantly different from zero (although point estimates are negative). Therefore, it is quite possible that such tax assignments would reduce deficits due to both greater expenditure decentralization and lower transfer dependence, while the direct effect of additional tax assignment might be negligible.

The above estimates are obtained using the ratio of primary budget balance to the consolidated tax and non-tax regional budget revenues. To check the robustness of our findings, we show that different versions of the dependent variable yield results that are qualitatively similar to those in Table 6. Table 7 presents fixed effects OLS estimates and Table 8 shows system-GMM estimates using ratios of primary budget balance to GRP as well as ratios of overall budget balance to consolidated regional budget revenues and to GRP.

One could argue that the inclusion of 2009 in our regressions might have skewed the results, because Russia went through a rather significant recession during that year. However, in our view, this does not invalidate our findings, because we exclude balancing grants from our regional budget balances and because the ability to manage budget deficits is particularly important during economic recessions. Nonetheless, we present our benchmark regressions, 
modified by the exclusion of 2009. As the estimates in Tables 9 and 10 demonstrate, the qualitative results excluding 2009 remain essentially the same.

We have shown that when we look separately at the effects of greater expenditure decentralization and greater transfer dependence, the former decreases regional budget deficits while the latter increases deficits. The reasons for the deficit-increasing effect of transfer dependence are fairly straightforward. Greater transfers may create an expectation of more transfers in the future and thus reduce the incentives to enhance own-revenue base or to be careful with spending budgetary funds. But why might expenditure decentralization reduce regional budget deficits even in a politically centralized federation such as Russia? We can think of two potential explanations for this finding. First, municipal governments may be more efficient at managing certain types of spending because they are closer to where this spending takes place and it is easier for them to monitor the use of funds. Of course, this advantage exists only if the municipal governments are themselves interested in spending efficiently (rather than, for instance, embezzling funds). In this regard, we note that although during 20052013 Russia did not have elections of regional governors, there were elections at the municipal level and these elections could in principle serve as a monitoring mechanism. We realize that those elections that were held during the period of our data generally involved predetermined outcomes (see, for example, Golosov 2008 and Gel'man and Lankina 2008). Nonetheless, the regional governors evaluate the performance of municipal leaders not only by the headline election results but also by the extent to which the elections are free of scandals and controversies. This aversion to negative publicity does make municipal authorities somewhat 
responsive to their local constituents. ${ }^{29}$ However, even if local authorities are accountable to the voters, this does not necessarily imply that they would be interested in budget discipline. For this reason, we do not emphasize local official accountability as an explanation for our results. Instead, our preferred conjecture is that it might be easier for a regional government to precommit to a certain level of expenditures when it allocates funds to its constituent municipalities rather than when it tries to fund various government tasks itself. For example, suppose a regional government wants to fund a construction project within a municipality. If the regional government funds the project directly and the funds prove insufficient for finishing it, the regional government would be directly responsible and would be under pressure to allocate additional funds. If, however, the project funding goes through an additional administrative layer of municipal authorities, the municipality would blame the region for insufficient funding and the region would blame the municipality for not spending funds efficiently. Knowing that additional funding is not forthcoming, the municipality and its contractor would be more likely to complete the project within the original budget. Of course, this mechanism requires that the regional government is interested in reducing its budget deficits. According to the political science literature (e.g., Gel'man and Ryzhenkov 2011), Russia's regional governors have only limited autonomy and are mostly beholden to the central government. But the central government is clearly interested in the regions exercising strong budget discipline. This is evidenced by the fact that the Budget Code proscribes deficits of regional budgets exceeding $15 \%$ of own regional revenues ( $10 \%$ for highly transfer dependent

\footnotetext{
${ }^{29}$ We make this this statement based on the personal experiences of one of us working with the municipal authorities in three different regions of the Russian Federation.
} 
regions). There are even tighter constraints on the deficits of municipal budgets. Also, there are fairly strict limitations on the size of regional and municipal commercial debt. Thus, the federal center presumably evaluates the performance of regional governors in part by how well they manage regional budgets. In addition, given that the regional governments are essentially residual claimants with respect to regional budgets, the governors might be interested in improving regional budget balances even if the aforementioned constraints on the deficits are not binding.

We stress, however, that although expenditure decentralization appears to reduce budget deficits, if this decentralization is achieved by greater transfers to municipalities, the effect on budget deficit is negative - presumably due to the largely discretionary nature of transfers. Instead, our estimates argue for increasing expenditure decentralization via assigning greater shares of tax revenue to municipalities, particularly if such additional tax assignments are made in a manner that limits the discretion of regional authorities.

\section{CONCLUSIONS}

Using three different econometric methods and several alternative specifications, we find that regional budget balances in Russia positively and statistically significantly depend on the degree of intraregional expenditure decentralization. However, budget balances are negatively affected by some of the tools that regional governments could use to decentralize expenditures. In particular, greater transfer dependence of municipal budgets and higher share of municipal budget revenues in consolidated regional budget revenue are associated with higher regional deficits (although the assignments of some of the regional tax revenues to 
municipalities appear to raise regional deficits only if these tax assignments have a highly discretionary nature). In this regard, we stress the importance of our finding of a significant regime change in intraregional fiscal relations in Russia in 2009 with respect to the role of nonPIT tax assignments. That regime change severely limited the discretion of regional governments with respect to non-PIT tax assignments, differentiating them from transfers. This has made it difficult for the regions to use non-PIT tax assignments as discretionary transfers and thus allowed for expenditure decentralization funded by non-PIT tax assignments to become a deficit-reducing device at the regional level. In fact, our estimates suggest that under the current fiscal federalism rules in Russia, regional deficits could be reduced, at least on average, if expenditure decentralization within an "average" region is increased via increased tax revenue assignments to municipalities, particularly if these assignments are made in a stable and predictable manner that leaves little room for discretion on the part of the regional government. Importantly, the policy relevance of these results has increased since 2014 because of significant reductions in real transfers from the federal budget to the regions.

Somewhat surprisingly, despite the relatively small degree of political and fiscal autonomy of municipalities within Russia's regions, our main results are in line with some of the empirical literature that examines the effect of fiscal decentralization on budget deficits in countries with a much greater degree of fiscal independence for subnational governments. We conjecture that expenditure decentralization in Russia's regions promotes regional budget discipline mainly because it is easier for the regional government to precommit to a given level of expenditures for particular projects when these expenditures are allocated to municipalities, which have harder budget constraints than the regional government. 


\section{REFERENCES}

Alexeev, Michael, and Shlomo Weber, 2013. "Russian Fiscal Federalism: Impact of Political and Fiscal (De)centralization," in Alexeev and Weber, Eds., The Oxford Handbook of the Russian Economy, Oxford University Press (also, CEPR Discussion Paper \#9356).

and Galina Kurlyandskaya, 2003. "Fiscal Federalism and Incentives in a Russian Region," Journal of Comparative Economics, 31:20-33.

Asatryan, Zareh, Lars P. Feld, and Benny Geys, 2015. "Partial Fiscal Decentralization and Sub-National Government Fiscal Discipline: Empirical Evidence From OECD Countries," Public Choice, 163: 307-20.

Baskaran, Thushyanthan, 2010. "On the link between fiscal decentralization and public debt in OECD countries," Public Choice, 145(3/4):351-378.

Blanchard, Olivier \& Andrei Shleifer, 2001. "Federalism With and Without Political Centralization: China Versus Russia," IMF Staff Papers, 48:171-179.

Dilger, Robert Jay, and Eugene Boyd, 2014. "Block Grants: Perspectives and Controversies," Congressional Research Service Report R40486.

Enikolopov, Ruben, and Ekaterina Zhuravskaya, 2007. "Decentralization and political institutions," Journal of Public Economics, 91:2261-2290.

Eyraud, L. and M. M. Badia, 2013. "Too small to fail? sub-national spending pressures in Europe", European Economy, Economic Papers, 501: 24-55.

Eyraud, L. and L. Lusinyan, 2013. "Vertical fiscal imbalances and fiscal performance in advanced economies," Journal of Monetary Economics, 60(5): 571-587.

Escolano, J., L. Eyraud, M. Moreno Badia, J. Sarnes, and A. Tuladhar, 2012. "Fiscal Performance, Institutional Design and Decentralization in European Union Countries," IMF Working Paper WP/12/4.5

Freitag, M. and A. Vatter, 2008. Decentralization and fiscal discipline in sub-national governments: evidence from the Swiss federal system. Publius: The Journal of Federalism 38(2): 272-294.

Foremny, Dirk, 2014. "Sub-national deficits in European countries: The impact of fiscal rules and tax autonomy," European Journal of Political Economy, 34:86-110. 
Gel'man, V., and Lankina T., 2008. "Authoritarian versus Democratic Diffusions: Explaining Institutional Choices in Russia's Local Government," Post-Soviet Affairs, 24(1):40-62.

Gel'man, V., and S. Ryzhenkov, 2011. "Local Regimes, Sub-national Governance and the 'Power Vertical' in Contemporary Russia," Europe-Asia Studies, 63(3):449-465.

Golosov, G. 2008. “Elektoral'nyi avtoritarizm v Rossii," Pro et Contra, 12(1):22-35.

Hall, A. R. 2005. Generalized Method of Moments. Oxford: Oxford University Press.

Neyapti, Bilin, 2010."Fiscal decentralization and deficits: International evidence" European Journal of Political Economy, 26(2):155-166.

Presbitero, A.F., A. Sacchi, and A. and Zazzaro, 2014. "Property tax and fiscal discipline in OECD countries," Economics Letters 124(3): 428-433.

Qian, Yingyi, and Gerard Roland, 1998. "Federalism and the Soft Budget Constraint," American Economic Review, 88(5):1143-61.

Riker, William H., 1964. Federalism: Origins, Operation, Significance, Little, Brown and Co, Boston, MA.

Rodden, Jonathan, 2002. "The Dilemma of Fiscal Federalism: Grants and Fiscal Performance around the World," American Journal of Political Science, 46(3):670-687.

Rodden, Jonathan, and Erik Wibbels, 2002. "Beyond the Fiction of Federalism: Macroeconomic Management in Multitiered Systems," World Politics 54: 494-531.

Roodman, David, 2009. "How to do xtabond2: An introduction to difference and system GMM in Stata," Stata Journal, 9(1):86-136.

Schaltegger, Christoph A., and Lars P. Feld, 2009. "Are Fiscal Adjustments Less Successful in Decentralized Governments?" European Journal of Political Economy 25: 115-123.

Shishkin, Dmitry, 2013. "Fiscal Incentives and Shared Revenue Sources with Differentiated Sharing Rates," Public Finance Review, 41(4):473-488

Treisman, Daniel, 2000. "Decentralization, Tax Evasion, and the Underground Economy: A Model with Evidence from Russia," mimeo, available at http://www.isr.umich.edu/cps/pewpa/archive/archive 00/20000004.pdf 
Zhuravskaya, Ekaterina, 2000. "Incentives to provide local public goods: fiscal federalism, Russian style," Journal of Public Economics, 76 (3):337-368. 
Table 1. Description of variables and sources

\begin{tabular}{|c|c|}
\hline Variable & Description \\
\hline $\begin{array}{l}\text { Gross regional } \\
\text { product (GRP) }\end{array}$ & $\begin{array}{l}\text { Gross regional product in nominal prices, million rubles. Source: Rosstat } \\
\text { (http://www.gks.ru/wps/wcm/connect/rosstat_main/rosstat/ru/statistics/accounts } \\
\text { /\#) }\end{array}$ \\
\hline Population & Region's population. Source: Rosstat (http://cbsd.gks.ru) \\
\hline Per capita GRP & $\begin{array}{l}\text { GRP in nominal prices divided by population, thousand rubles. Source: authors' } \\
\text { calculations based on the variables defined above. }\end{array}$ \\
\hline $\begin{array}{l}\text { Regional growth } \\
\text { rate }\end{array}$ & $\begin{array}{l}\text { Deviation of the index of physical volume GRP from the geometric mean for } \\
\text { 2009-2013. Source: authors' calculations based on Rosstat GRP data (see } \\
\text { above). }\end{array}$ \\
\hline $\begin{array}{l}\text { Consolidated } \\
\text { regional debt }\end{array}$ & $\begin{array}{l}\text { The combined debt of the regional government and municipal authorities as of } \\
\text { the end of the year, excluding loan guarantees issued by either regional } \\
\text { government or municipal authorities and intraregional budget loans. Source: } \\
\text { Russia's Ministry of Finance } \\
\text { (http://Mинфин.pф/ru/public_debt/subdbt/index.php?\&from_4=1); not all data } \\
\text { are publicly available. }\end{array}$ \\
\hline $\begin{array}{l}\text { Total budget } \\
\text { revenue excluding } \\
\text { transfers }\end{array}$ & $\begin{array}{l}\text { The sum of tax and non-tax revenue of regional and municipal budgets } \\
\text { (excluding transfers). Source: authors' calculations based on Federal Treasury's } \\
\text { data (http://roskazna.ru/byudzhetov-subektov-rf-i-mestnykh-byudzhetov/) }\end{array}$ \\
\hline $\begin{array}{l}\text { Consolidated } \\
\text { budget balance }\end{array}$ & $\begin{array}{l}\text { The difference between total budget revenue, including transfers from the } \\
\text { federal budget (except for balancing grants), and expenditures of consolidated } \\
\text { (combined) regional and municipal budgets. Source: Federal Treasury } \\
\text { (http://roskazna.ru/byudzhetov-subektov-rf-i-mestnykh-byudzhetov ) }\end{array}$ \\
\hline $\begin{array}{l}\text { Transfers from } \\
\text { regional budget to } \\
\text { municipal budgets }\end{array}$ & $\begin{array}{l}\text { Transfers as indicated on the expenditure side of regional budget less transfers } \\
\text { indicated on the expenditure side of consolidated regional budget plus other } \\
\text { transfers received by extra-budgetary funds from urban and municipal } \\
\text { districts. Source: authors' calculations based on the Federal Treasury data } \\
\text { (http://roskazna.ru/byudzhetov-subektov-rf-i-mestnykh-byudzhetov/) }\end{array}$ \\
\hline Subventions & $\begin{array}{l}\text { Subventions from regional to municipal budgets. Prior to } 2010 \text { - as indicated } \\
\text { on the expenditure side of the regional budget; starting in } 2010 \text { - the sum of } \\
\text { subvention revenue of municipal districts and subvention revenue of urban } \\
\text { districts. Source: authors' calculations based on the Federal Treasury data } \\
\text { (http://roskazna.ru/byudzhetov-subektov-rf-i-mestnykh-byudzhetov/) }\end{array}$ \\
\hline Balancing grants & $\begin{array}{l}\text { Grants from the federal budget aimed at reducing regional budget deficit } \\
\text { (dotatsii na sbalansirovannost'). Source: Federal Treasury } \\
\text { (http://roskazna.ru/byudzhetov-subektov-rf-i-mestnykh-byudzhetov/ ) }\end{array}$ \\
\hline $\begin{array}{l}\text { Mining industry } \\
\text { share }\end{array}$ & $\begin{array}{l}\text { Share (in percent) of mining industry in GRP. Source: authors' calculations } \\
\text { based on the Federal Tax Service data } \\
\text { (http://www.nalog.ru/rn77/related_activities/statistics_and_analytics/forms/) }\end{array}$ \\
\hline $\begin{array}{l}\text { Primary balance of } \\
\text { consolidated budget }\end{array}$ & $\begin{array}{l}\text { Consolidated budget balance plus expenditures of consolidated budget on } \\
\text { servicing consolidated debt minus balancing grants from the federal budget. } \\
\text { Source: authors' calculations based on Federal Treasury data } \\
\text { (http://roskazna.ru/byudzhetov-subektov-rf-i-mestnykh-byudzhetov ) }\end{array}$ \\
\hline
\end{tabular}




\begin{tabular}{|c|c|}
\hline $\begin{array}{l}\text { Ratio of budget } \\
\text { balance and } \\
\text { consolidated tax } \\
\text { and non-tax } \\
\text { revenue }\end{array}$ & $\begin{array}{l}\text { Ratio (in percent) of the balance of consolidated budget to consolidated tax } \\
\text { and non-tax revenue. Source: authors calculations based on the values defined } \\
\text { above. }\end{array}$ \\
\hline $\begin{array}{l}\text { Ratio of budget } \\
\text { balance and GRP }\end{array}$ & $\begin{array}{l}\text { Ratio (in percent) of the balance of consolidated budget to GRP. Source: } \\
\text { authors calculations based on the values defined above }\end{array}$ \\
\hline $\begin{array}{l}\text { Ratio of primary } \\
\text { budget balance and } \\
\text { consolidated tax } \\
\text { and non-tax } \\
\text { revenue }\end{array}$ & $\begin{array}{l}\text { Ratio (in percent) of primary balance of consolidated budget to consolidated } \\
\text { tax and non-tax revenue. Source: authors calculations based on the values } \\
\text { defined above. }\end{array}$ \\
\hline $\begin{array}{l}\text { Ratio of primary } \\
\text { balance and GRP }\end{array}$ & $\begin{array}{l}\text { Ratio (in percent) of primary balance of consolidated budget to GRP. Source: } \\
\text { authors calculations based on the values defined above. }\end{array}$ \\
\hline $\begin{array}{l}\text { Expenditure } \\
\text { decentralization } \\
\text { (without } \\
\text { subventions) }\end{array}$ & $\begin{array}{l}\text { Expenditure decentralization without counting subventions from the regional } \\
\text { budget, calculated as } \\
100 \times\left(1-\frac{\text { regional budget expenditures-transfers }+ \text { subventions }}{\text { consolidated budget expenditures-consolidated subventions }}\right) \\
\text { Source: authors' calculations based on the Federal Treasury data } \\
\text { (http://roskazna.ru/byudzhetov-subektov-rf-i-mestnykh-byudzhetov/) }\end{array}$ \\
\hline $\begin{array}{l}\text { Municipal revenue } \\
\text { share }\end{array}$ & $\begin{array}{l}\text { Share (in percent) of tax revenue of municipal budgets in tax revenue of } \\
\text { consolidated budget. Source: authors' calculations based on the Federal } \\
\text { Treasury data (http://roskazna.ru/byudzhetov-subektov-rf-i-mestnykh- } \\
\text { byudzhetov/ ) }\end{array}$ \\
\hline $\begin{array}{l}\text { Municipal share of } \\
\text { PIT }\end{array}$ & $\begin{array}{l}\text { Share (in percent) of PIT revenue of municipal budgets in PIT revenue of } \\
\text { consolidated budget. Source: authors' calculations based on the Federal } \\
\text { Treasury data (http://roskazna.ru/byudzhetov-subektov-rf-i-mestnykh- } \\
\text { byudzhetov/) }\end{array}$ \\
\hline $\begin{array}{l}\text { Municipal share of } \\
\text { taxes other than PIT }\end{array}$ & $\begin{array}{l}\text { Share (in percent) of non-PIT tax revenue of municipal budgets in non-PIT tax } \\
\text { revenue of consolidated budget. Source: authors' calculations based on the } \\
\text { Federal Treasury data (http://roskazna.ru/byudzhetov-subektov-rf-i-mestnykh- } \\
\text { byudzhetov/) }\end{array}$ \\
\hline $\begin{array}{l}\text { Transfer } \\
\text { dependence } \\
\text { (without } \\
\text { subventions) }\end{array}$ & $\begin{array}{l}\text { The degree to which municipal budgets depend on transfers, calculated as } \\
100 \times \frac{\text { transfers-subventions }}{\text { tax\&nontax municipal revenue+transfers-subventions }} \text {. Municipal revenue is } \\
\text { calculated as the difference between consolidated budget revenue and } \\
\text { revenue of the regional budget. Source: authors' calculations based on the } \\
\text { Federal Treasury data (http://roskazna.ru/byudzhetov-subektov-rf-i-mestnykh- } \\
\text { byudzhetov/) }\end{array}$ \\
\hline $\begin{array}{l}\text { Ratio of } \\
\text { consolidated } \\
\text { regional debt to tax } \\
\text { and non-tax } \\
\text { revenue }\end{array}$ & $\begin{array}{l}\text { The ratio (in percent) of consolidated debt to the tax and non-tax } \\
\text { revenue. Source: authors' calculations based on the values of } \\
\text { consolidated debt and tax and non-tax revenue (see above). }\end{array}$ \\
\hline
\end{tabular}


Table 2. Descriptive statistics (2009-2013)

\begin{tabular}{|l|c|c|c|c|}
\hline & Mean & $\begin{array}{c}\text { Standard } \\
\text { deviation }\end{array}$ & Minimum & Maximum \\
\hline Budget balance/budget revenue (\%) & -7.74 & 10.51 & -54.64 & 39.74 \\
\hline $\begin{array}{l}\text { Budget balance/budget revenue excl. balancing } \\
\text { grants (\%) }\end{array}$ & -11.37 & 11.76 & -72.44 & 38.14 \\
\hline Budget balance/GRP (\%) & -0.96 & 1.36 & -7.09 & 5.17 \\
\hline Budget balance/GRP excl. balancing grants (\%) & -1.42 & 1.50 & -9.39 & 4.67 \\
\hline Primary balance/budget revenue (\%) & -6.18 & 10.16 & -53.72 & 40.85 \\
\hline $\begin{array}{l}\text { Primary balance/budget revenue excl. } \\
\text { balancing grants (\%) }\end{array}$ & -9.82 & 11.32 & -71.52 & 39.25 \\
\hline Primary balance/GRP (\%) & -0.76 & 1.31 & -6.97 & 5.33 \\
\hline Primary balance/GRP excl. balancing grants (\%) & -1.22 & 1.44 & -9.27 & 4.84 \\
\hline Expenditure decentralization (\%) & 29.37 & 6.92 & 12.76 & 51.62 \\
\hline Municipal revenue share (\%) & 25.91 & 4.83 & 13.27 & 53.74 \\
\hline Municipal share of PIT (\%) & 41.51 & 3.88 & 29.99 & 60 \\
\hline Municipal share of taxes other than PIT (\%) & 14.76 & 6.14 & 2.47 & 38.87 \\
\hline Transfer dependence (\%) & 43.93 & 10.84 & 20.56 & 78.39 \\
\hline $\begin{array}{l}\text { Lagged consolidated debt/total budget revenue } \\
\text { excl. transfers (\%) }\end{array}$ & 25.14 & 19.17 & 0.00 & 133.51 \\
\hline Mining value added/GRP (\%) & 7.18 & 11.47 & .00 & 61.60 \\
\hline Lagged per capita GRP (thousand 2005 rubles) & 109.03 & 53.77 & 35.66 & 413.28 \\
\hline Annual growth rate of real GRP & 1.02 & 0.05 & .80 & 1.17 \\
\hline Population (mid-year; thousands) & $1,569.08$ & $1,122.82$ & 151.33 & $5,367.23$ \\
\hline
\end{tabular}

Note: all descriptive statistics are based on 360 observations 
Table 3. Pairwise correlations of the main fiscal and economic variables

\begin{tabular}{|l|c|l|l|l|l|l|l|l|}
\hline & $\begin{array}{l}\text { Balance/ } \\
\text { revenue }\end{array}$ & $\begin{array}{l}\text { Primary } \\
\text { balance/ } \\
\text { revenue }\end{array}$ & $\begin{array}{l}\text { Primary } \\
\text { balance/ } \\
\text { GRP }\end{array}$ & $\begin{array}{l}\text { Expenditure } \\
\text { decentra- } \\
\text { lization }\end{array}$ & $\begin{array}{l}\text { Municipal } \\
\text { revenue } \\
\text { share }\end{array}$ & $\begin{array}{l}\text { Transfer } \\
\text { depen- } \\
\text { dence }\end{array}$ & $\begin{array}{l}\text { Consoli- } \\
\text { dated } \\
\text { debt/ } \\
\text { revenue }\end{array}$ & $\begin{array}{l}\text { Growth } \\
\text { rate } \\
\text { GRP }\end{array}$ \\
\hline Balance/ revenue & 1.000 & & & & & & \\
\hline $\begin{array}{l}\text { Primary balance/ } \\
\text { Revenue }\end{array}$ & .994 & 1.000 & & & & & \\
\hline $\begin{array}{l}\text { Primary balance/ } \\
\text { GRP }\end{array}$ & .968 & .972 & 1.000 & & & & \\
\hline $\begin{array}{l}\text { Expenditure } \\
\text { decentralization }\end{array}$ & .198 & .184 & .153 & 1.000 & & & \\
\hline $\begin{array}{l}\text { Municipal } \\
\text { revenue share }\end{array}$ & -.027 & -.028 & -.032 & -.072 & 1.000 & & \\
\hline $\begin{array}{l}\text { Transfer } \\
\text { dependence }\end{array}$ & -.096 & -.108 & -.064 & .102 & -.034 & 1.000 & & \\
\hline $\begin{array}{l}\text { Consolidated } \\
\text { debt/ } \\
\text { revenue }\end{array}$ & -.507 & -.440 & -.423 & -.351 & -.019 & .036 & 1.000 & \\
\hline Growth rate & .154 & .156 & .206 & -.059 & -.112 & .062 & .016 & 1.000 \\
\hline PC GRP & .153 & .139 & .151 & .478 & -.395 & .234 & -.238 & .093 \\
\hline
\end{tabular}


Table 4. Budget discipline and fiscal decentralization, 2005-2013

Dependent variable: Primary balance/revenue

\begin{tabular}{|c|c|c|c|c|}
\hline \multirow[b]{2}{*}{ VARIABLES } & \multicolumn{2}{|c|}{ OLS fixed effects } & \multicolumn{2}{|c|}{ System-GMM } \\
\hline & (1) & (2) & (3) & (4) \\
\hline Dependent variable (t-1) & & & $\begin{array}{c}0.258^{* *} \\
(0.119)\end{array}$ & $\begin{array}{c}0.277^{* * *} \\
(0.098)\end{array}$ \\
\hline Expenditure decentralization & $\begin{array}{c}0.631^{* * *} \\
(0.204)\end{array}$ & $\begin{array}{l}0.520^{* *} \\
(0.200)\end{array}$ & $\begin{array}{c}0.836^{* *} \\
(0.338)\end{array}$ & $\begin{array}{l}0.402^{*} \\
(0.234)\end{array}$ \\
\hline Municipal share of all taxes & $\begin{array}{c}-1.034^{* * *} \\
(0.280)\end{array}$ & & $\begin{array}{c}-1.360 * * * \\
(0.500)\end{array}$ & \\
\hline $\begin{array}{l}\text { Municipal share of non-PIT } \\
\text { taxes }\end{array}$ & & $\begin{array}{l}-0.329^{*} \\
(0.194)\end{array}$ & & $\begin{array}{l}-0.312 \\
(0.308)\end{array}$ \\
\hline Municipal share of PIT & & $\begin{array}{c}-0.467^{* * *} \\
(0.146)\end{array}$ & & $\begin{aligned}-0.358^{*} \\
(0.211)\end{aligned}$ \\
\hline Transfer dependence & $\begin{array}{c}-0.619 * * * \\
(0.128)\end{array}$ & $\begin{array}{c}-0.518 * * * \\
(0.116)\end{array}$ & $\begin{array}{c}-0.770^{* * *} \\
(0.296)\end{array}$ & $\begin{array}{c}-0.529 * * \\
(0.228)\end{array}$ \\
\hline Consolidated debt/Rev (t-1) & $\begin{array}{c}0.016 \\
(0.069)\end{array}$ & $\begin{array}{c}0.008 \\
(0.066)\end{array}$ & $\begin{array}{l}-0.249 \\
(0.188)\end{array}$ & $\begin{array}{l}-0.163 \\
(0.102)\end{array}$ \\
\hline $\begin{array}{l}\text { Log of Real per capita GRP } \\
\text { (t-1) }\end{array}$ & $\begin{array}{c}-23.892 * * * \\
(8.537)\end{array}$ & $\begin{array}{c}-16.090^{*} \\
(8.142)\end{array}$ & $\begin{array}{l}-33.286^{*} \\
(17.623)\end{array}$ & $\begin{array}{l}-15.279 \\
(10.196)\end{array}$ \\
\hline Share of mining in GRP & $\begin{array}{c}0.060 \\
(0.132)\end{array}$ & $\begin{array}{c}0.187 \\
(0.133)\end{array}$ & $\begin{array}{c}0.534 \\
(0.388)\end{array}$ & $\begin{array}{c}0.486^{* *} \\
(0.223)\end{array}$ \\
\hline Log of population & $\begin{array}{l}-34.484 \\
(45.400)\end{array}$ & $\begin{array}{l}-27.221 \\
(46.041)\end{array}$ & $\begin{array}{c}0.751 \\
(6.186)\end{array}$ & $\begin{array}{c}1.883 \\
(3.681)\end{array}$ \\
\hline Growth rate of real GRP & $\begin{array}{c}0.030 \\
(11.966)\end{array}$ & $\begin{array}{c}5.666 \\
(12.206)\end{array}$ & $\begin{array}{l}-11.291 \\
(23.081)\end{array}$ & $\begin{array}{c}1.409 \\
(15.880)\end{array}$ \\
\hline Hansen J p-value & & & 0.178 & 0.168 \\
\hline$A R(2) p$-value & & & 0.244 & 0.317 \\
\hline R-squared (within) & 0.294 & 0.273 & & \\
\hline Observations & 576 & 576 & 576 & 576 \\
\hline Number of instruments & & & 26 & 38 \\
\hline Number of regions & 72 & 72 & 72 & 72 \\
\hline
\end{tabular}

Notes: Significance levels for coefficient estimates: ${ }^{* * *}-1 \%$; ${ }^{* *}-5 \%$; ${ }^{*}-10 \%$;

Robust standard errors adjusted for clustering by regions are in parentheses;

All regressions contain dummy variables for years 
Table 5. Budget discipline and fiscal decentralization with interactive terms, 2005-2013

Dependent variable: Primary balance/revenue

\begin{tabular}{|c|c|c|c|c|}
\hline \multirow[b]{2}{*}{ VARIABLES } & \multicolumn{2}{|c|}{ OLS fixed effects } & \multicolumn{2}{|c|}{ System-GMM } \\
\hline & (1) & $(2)$ & (3) & (4) \\
\hline \multirow[t]{2}{*}{ Dependent variable ( $t-1)$} & & & $0.297 * * *$ & $0.287^{* * *}$ \\
\hline & & & $(0.110)$ & $(0.091)$ \\
\hline \multirow[t]{2}{*}{ Expenditure decentralization } & $0.528 * * *$ & $0.436 * *$ & $0.466^{*}$ & 0.366 \\
\hline & $(0.190)$ & $(0.189)$ & $(0.245)$ & $(0.227)$ \\
\hline \multirow[t]{2}{*}{ Expenditure decentralization $\times$ post- 2008} & 0.316 & 0.255 & 0.093 & 0.126 \\
\hline & $(0.209)$ & $(0.203)$ & $(0.612)$ & $(0.452)$ \\
\hline \multirow[t]{2}{*}{ Municipal share of all taxes } & $-1.261 * * *$ & & $-0.874 * *$ & \\
\hline & $(0.297)$ & & $(0.377)$ & \\
\hline \multirow[t]{2}{*}{ Municipal share of all taxes×post-2008 } & $0.508^{*}$ & & -0.297 & \\
\hline & $(0.279)$ & & $(0.801)$ & \\
\hline \multirow[t]{2}{*}{ Municipal share of non-PIT taxes } & & $-0.597 * * *$ & & -0.377 \\
\hline & & $(0.204)$ & & $(0.340)$ \\
\hline Municipal share of non-PIT & & $0.473^{*}$ & & 0.105 \\
\hline taxes×post- 2008 & & $(0.243)$ & & $(0.498)$ \\
\hline \multirow[t]{2}{*}{ Municipal share of PIT } & & $-0.448 * * *$ & & -0.305 \\
\hline & & $(0.167)$ & & $(0.213)$ \\
\hline \multirow[t]{2}{*}{ Municipal share of PIT× post-2008 } & & -0.082 & & -0.075 \\
\hline & & $(0.155)$ & & $(1.594)$ \\
\hline \multirow[t]{2}{*}{ Transfer dependence } & $-0.668 * * *$ & $-0.576 * * *$ & $-0.586 * *$ & $-0.445^{*}$ \\
\hline & (0.144) & $(0.136)$ & $(0.267)$ & $(0.246)$ \\
\hline \multirow[t]{2}{*}{ Transfer dependence $\times$ post- 2008} & 0.088 & 0.113 & -0.210 & -0.204 \\
\hline & $(0.112)$ & $(0.111)$ & $(0.242)$ & $(0.237)$ \\
\hline \multirow[t]{2}{*}{ Consolidated debt/Rev (t-1) } & 0.044 & 0.031 & -0.153 & -0.143 \\
\hline & $(0.061)$ & $(0.058)$ & $(0.133)$ & $(0.098)$ \\
\hline \multirow{2}{*}{$\begin{array}{l}\text { Log of Real per capita GRP } \\
(\mathrm{t}-1)\end{array}$} & $-22.992 * *$ & $-19.276 * *$ & -17.720 & -13.444 \\
\hline & (9.035) & $(8.706)$ & $(14.158)$ & (9.097) \\
\hline \multirow[t]{2}{*}{ Share of mining in GRP } & 0.000 & 0.152 & 0.505 & $0.445^{* *}$ \\
\hline & $(0.148)$ & $(0.159)$ & $(0.393)$ & $(0.225)$ \\
\hline \multirow[t]{2}{*}{ Log of population } & -43.235 & -41.796 & 2.095 & 2.276 \\
\hline & $(40.288)$ & $(40.423)$ & $(4.908)$ & $(4.040)$ \\
\hline \multirow[t]{2}{*}{ Growth rate of real GRP } & 5.386 & 8.817 & -2.036 & 4.046 \\
\hline & $(12.786)$ & (12.778) & $(23.205)$ & $(15.506)$ \\
\hline Hansen J p-value & & & 0.180 & 0.145 \\
\hline$A R(2) p$-value & & & 0.403 & 0.349 \\
\hline R-squared (within) & 0.318 & 0.299 & & \\
\hline Observations & 576 & 576 & 576 & 576 \\
\hline Number of instruments & & & 35 & 38 \\
\hline Number of regions & 72 & 72 & 72 & 72 \\
\hline
\end{tabular}

Notes: Significance levels for coefficient estimates: $* * *-1 \%$; ${ }^{*}-5 \%$; ${ }^{*}-10 \%$;

Robust standard errors adjusted for clustering by regions are in parentheses;

All regressions contain dummy variables for years 
Table 6. Budget discipline and fiscal decentralization, 2009-2013

Dependent variable: Primary balance/revenue

\begin{tabular}{|c|c|c|c|c|}
\hline \multirow[b]{2}{*}{ VARIABLES } & \multicolumn{2}{|c|}{ OLS fixed effects } & \multicolumn{2}{|c|}{ System-GMM } \\
\hline & (1) & (2) & (3) & (4) \\
\hline Dependent variable $(t-1)$ & & & $\begin{array}{c}0.325^{* * *} \\
(0.109)\end{array}$ & $\begin{array}{c}0.310^{* * *} \\
(0.105)\end{array}$ \\
\hline Expenditure decentralization & $\begin{array}{c}1.090^{* * *} \\
(0.282)\end{array}$ & $\begin{array}{c}0.940 * * * \\
(0.298)\end{array}$ & $\begin{array}{c}0.940^{* * *} \\
(0.345)\end{array}$ & $\begin{array}{c}0.846^{* * *} \\
(0.327)\end{array}$ \\
\hline Municipal share of all taxes & $\begin{array}{l}-0.815^{*} \\
(0.427)\end{array}$ & & $\begin{array}{l}-0.632^{*} \\
(0.350)\end{array}$ & \\
\hline $\begin{array}{l}\text { Municipal share of non-PIT } \\
\text { taxes }\end{array}$ & & $\begin{array}{l}-0.174 \\
(0.376)\end{array}$ & & $\begin{array}{l}-0.208 \\
(0.289)\end{array}$ \\
\hline Municipal share of PIT & & $\begin{array}{c}-0.469 * * * \\
(0.155)\end{array}$ & & $\begin{array}{c}-0.697^{* *} \\
(0.319)\end{array}$ \\
\hline Transfer dependence & $\begin{array}{c}-0.713^{* * *} \\
(0.162)\end{array}$ & $\begin{array}{c}-0.627^{* * *} \\
(0.171)\end{array}$ & $\begin{array}{c}-0.907^{* * *} \\
(0.250)\end{array}$ & $\begin{array}{c}-0.804^{* * *} \\
(0.208)\end{array}$ \\
\hline Consolidated debt/Rev (t-1) & $\begin{array}{c}0.179 * * \\
(0.088)\end{array}$ & $\begin{array}{c}0.187^{* *} \\
(0.087)\end{array}$ & $\begin{array}{l}-0.112 \\
(0.126)\end{array}$ & $\begin{array}{l}-0.106 \\
(0.113)\end{array}$ \\
\hline $\begin{array}{l}\text { Log of Real per capita GRP } \\
\text { (t-1) }\end{array}$ & $\begin{array}{c}-28.755^{* *} \\
(13.892)\end{array}$ & $\begin{array}{l}-23.514 \\
(14.857)\end{array}$ & $\begin{array}{l}-19.971 \\
(13.368)\end{array}$ & $\begin{array}{l}-18.166 \\
(11.511)\end{array}$ \\
\hline Share of mining in GRP & $\begin{array}{c}0.393 \\
(0.282)\end{array}$ & $\begin{array}{l}0.535^{*} \\
(0.291)\end{array}$ & $\begin{array}{c}0.303 \\
(0.368)\end{array}$ & $\begin{array}{c}0.398 \\
(0.316)\end{array}$ \\
\hline Log of population & $\begin{array}{l}82.051 \\
(65.251)\end{array}$ & $\begin{array}{c}90.913 \\
(66.678)\end{array}$ & $\begin{array}{c}2.067 \\
(6.235)\end{array}$ & $\begin{array}{c}3.434 \\
(5.881)\end{array}$ \\
\hline Growth rate of real GRP & $\begin{array}{c}-5.069 \\
(16.977)\end{array}$ & $\begin{array}{c}2.221 \\
(17.261)\end{array}$ & $\begin{array}{c}13.827 \\
(18.733)\end{array}$ & $\begin{array}{c}12.193 \\
(18.851)\end{array}$ \\
\hline Hansen J p-value & & & 0.679 & 0.595 \\
\hline AR(2) $p$-value & & & 0.123 & 0.211 \\
\hline R-squared (within) & 0.284 & 0.277 & & \\
\hline Observations & 360 & 360 & 360 & 360 \\
\hline Number of instruments & & & 33 & 36 \\
\hline Number of regions & 72 & 72 & 72 & 72 \\
\hline
\end{tabular}

Notes: Significance levels for coefficient estimates: ${ }^{* * *}-1 \%$; ${ }^{* *}-5 \%$; ${ }^{*}-10 \%$;

Robust standard errors adjusted for clustering by regions are in parentheses;

All regressions contain dummy variables for years; 
Table 7. Budget discipline and fiscal decentralization for alternative measures of budget balance, 2009-2013 (fixed effects; within estimator)

\begin{tabular}{|c|c|c|c|c|c|c|}
\hline \multirow{2}{*}{$\begin{array}{l}\text { Dependent variable: } \\
\text { VARIABLES }\end{array}$} & \multicolumn{2}{|c|}{ Primary balance/GRP } & \multicolumn{2}{|c|}{ Balance/revenue } & \multicolumn{2}{|c|}{ Balance/GRP } \\
\hline & $(1)$ & $(2)$ & $(4)$ & (3) & (5) & (6) \\
\hline Expenditure & $0.148 * * *$ & $0.131 * * *$ & $0.889 * * *$ & $0.786 * *$ & $0.121 * * *$ & $0.111 * * *$ \\
\hline decentralization & $(0.035)$ & $(0.037)$ & $(0.286)$ & $(0.303)$ & $(0.036)$ & $(0.038)$ \\
\hline Municipal share of & -0.084 & & -0.693 & & -0.066 & \\
\hline all taxes & (0.059) & & $(0.463)$ & & $(0.065)$ & \\
\hline Municipal share of & & -0.011 & & -0.192 & & -0.013 \\
\hline non-PIT taxes & & $(0.052)$ & & (0.378) & & $(0.054)$ \\
\hline Municipal share of & & $-0.076 * * *$ & & $-0.515^{* *}$ & & $-0.076 * * *$ \\
\hline PIT & & $(0.021)$ & & $(0.204)$ & & $(0.024)$ \\
\hline Transfer & $-0.087 * * *$ & $-0.078 * * *$ & $-0.594 * * *$ & $-0.536 * * *$ & $-0.071 * * *$ & $-0.066 * * *$ \\
\hline dependence & $(0.020)$ & $(0.021)$ & $(0.158)$ & $(0.163)$ & $(0.020)$ & $(0.020)$ \\
\hline Consolidated debt/ & $0.024^{* *}$ & $0.024 * *$ & $0.156 * *$ & $0.161^{* * *}$ & $0.021 * *$ & $0.021 * * *$ \\
\hline Revenue (t-1) & $(0.011)$ & $(0.011)$ & $(0.063)$ & $(0.061)$ & $(0.008)$ & $(0.008)$ \\
\hline Log of Real per & $-3.247^{*}$ & -2.463 & $-31.134 * *$ & $-26.340 *$ & $-3.447^{*}$ & -2.758 \\
\hline capita GRP (t-1) & $(1.715)$ & $(1.708)$ & $(14.153)$ & $(14.692)$ & $(1.797)$ & $(1.778)$ \\
\hline Share of mining in & 0.064 & $0.079 * *$ & 0.394 & $0.511 * *$ & $0.062^{*}$ & $0.074 * *$ \\
\hline GRP & $(0.040)$ & $(0.039)$ & $(0.245)$ & $(0.237)$ & $(0.034)$ & $(0.032)$ \\
\hline \multirow[t]{2}{*}{ Log of population } & 11.906 & 13.656 & $113.753 *$ & $122.329 *$ & $15.381^{* *}$ & $16.959 * *$ \\
\hline & (8.464) & $(8.465)$ & $(61.757)$ & (63.310) & (7.694) & $(7.783)$ \\
\hline Growth rate of real & 0.797 & 1.736 & -9.184 & -3.365 & 0.174 & 0.900 \\
\hline GRP & $(2.000)$ & $(2.255)$ & $(15.802)$ & $(16.213)$ & $(2.095)$ & $(2.178)$ \\
\hline R-squared (within) & 0.282 & 0.286 & 0.244 & 0.243 & 0.237 & 0.246 \\
\hline Observations & 360 & 360 & 360 & 360 & 360 & 360 \\
\hline Number of regions & 72 & 72 & 72 & 72 & 72 & 72 \\
\hline
\end{tabular}

Notes: Significance levels for coefficient estimates: ${ }^{* *}-1 \%$; ${ }^{* *}-5 \%$; ${ }^{*}-10 \%$;

Robust standard errors adjusted for clustering by regions are in parentheses;

All regressions contain dummy variables for years 
Table 8. Budget discipline and fiscal decentralization for alternative measures of budget balance, 2009-2013 (system-GMM estimator)

\begin{tabular}{|c|c|c|c|c|c|c|}
\hline \multirow[t]{2}{*}{ Dependent variable: } & \multicolumn{2}{|c|}{$\begin{array}{c}\text { Primary balance } \\
\text { /GRP }\end{array}$} & \multicolumn{2}{|c|}{ Balance/revenue } & \multicolumn{2}{|c|}{ Balance/GRP } \\
\hline & $(1)$ & $(2)$ & (3) & $(4)$ & $(5)$ & (6) \\
\hline Dependent variable $(t-1)$ & $\begin{array}{c}0.313^{* * *} \\
(0.114)\end{array}$ & $\begin{array}{c}0.292^{* * *} \\
(0.109)\end{array}$ & $\begin{array}{c}0.339 * * * \\
(0.109)\end{array}$ & $\begin{array}{c}0.322^{* * *} \\
(0.106)\end{array}$ & $\begin{array}{c}0.331^{* * *} \\
(0.115)\end{array}$ & $\begin{array}{c}0.307^{* * *} \\
(0.109)\end{array}$ \\
\hline $\begin{array}{l}\text { Expenditure } \\
\text { decentralization }\end{array}$ & $\begin{array}{c}0.117^{* * *} \\
(0.041)\end{array}$ & $\begin{array}{c}0.111 * * * \\
(0.041)\end{array}$ & $\begin{array}{c}0.934 * * * \\
(0.344)\end{array}$ & $\begin{array}{c}0.844^{* * *} \\
(0.324)\end{array}$ & $\begin{array}{c}0.115^{* * *} \\
(0.041)\end{array}$ & $\begin{array}{c}0.109 * * * \\
(0.041)\end{array}$ \\
\hline $\begin{array}{l}\text { Municipal share of } \\
\text { all taxes }\end{array}$ & $\begin{array}{l}-0.052 \\
(0.044)\end{array}$ & & $\begin{array}{l}-0.612^{*} \\
(0.351)\end{array}$ & & $\begin{array}{l}-0.046 \\
(0.044)\end{array}$ & \\
\hline $\begin{array}{l}\text { Municipal share of } \\
\text { non-PIT taxes }\end{array}$ & & $\begin{array}{l}-0.004 \\
(0.037)\end{array}$ & & $\begin{array}{l}-0.187 \\
(0.291)\end{array}$ & & $\begin{array}{c}0.001 \\
(0.037)\end{array}$ \\
\hline $\begin{array}{l}\text { Municipal share of } \\
\text { PIT }\end{array}$ & & $\begin{array}{c}-0.082^{* *} \\
(0.038)\end{array}$ & & $\begin{array}{c}-0.704^{* *} \\
(0.316)\end{array}$ & & $\begin{array}{c}-0.082^{* *} \\
(0.038)\end{array}$ \\
\hline Transfer & - & - & $-0.909 * * *$ & $-0.802 * * *$ & $-0.105^{* * *}$ & $-0.096 * * *$ \\
\hline dependence & $\begin{array}{c}0.107^{* * *} \\
(0.032)\end{array}$ & $\begin{array}{c}0.097^{* * *} \\
(0.027)\end{array}$ & $(0.256)$ & $(0.213)$ & $(0.032)$ & $(0.027)$ \\
\hline Consolidated debt/ & -0.010 & -0.010 & -0.147 & -0.141 & -0.014 & -0.013 \\
\hline Revenue (t-1) & $(0.014)$ & $(0.012)$ & $(0.128)$ & $(0.116)$ & $(0.014)$ & $(0.012)$ \\
\hline Log of Real per & -2.285 & -2.152 & -19.780 & -17.831 & -2.208 & -2.078 \\
\hline capita GRP (t-1) & $(1.514)$ & $(1.362)$ & $(13.220)$ & $(11.309)$ & $(1.480)$ & $(1.339)$ \\
\hline Share of mining in & 0.044 & 0.054 & 0.295 & 0.388 & 0.043 & 0.052 \\
\hline GRP & $(0.045)$ & $(0.040)$ & $(0.374)$ & $(0.321)$ & $(0.046)$ & $(0.041)$ \\
\hline Log of population & 0.299 & 0.416 & 2.034 & 3.399 & 0.308 & 0.420 \\
\hline & $(0.748)$ & $(0.692)$ & $(6.237)$ & $(5.845)$ & $(0.739)$ & $(0.681)$ \\
\hline Growth rate of real & 3.681 & 3.381 & 15.548 & 13.756 & $4.045^{*}$ & 3.714 \\
\hline GRP & $(2.316)$ & (2.309) & $(18.748)$ & $(18.845)$ & $(2.312)$ & $(2.311)$ \\
\hline Hansen J p-value & 0.107 & 0.190 & 0.109 & 0.204 & 0.087 & 0.177 \\
\hline$A R(2) p$-value & 0.505 & 0.479 & 0.605 & 0.529 & 0.435 & 0.425 \\
\hline Observations & 360 & 360 & 360 & 360 & 360 & 360 \\
\hline Number of instruments & 33 & 36 & 33 & 36 & 33 & 36 \\
\hline Number of regions & 72 & 72 & 72 & 72 & 72 & 72 \\
\hline
\end{tabular}

Notes: Significance levels for coefficient estimates: ${ }^{* *}-1 \% ;{ }^{* *}-5 \%{ }^{*}-10 \%$;

Robust standard errors adjusted for clustering by regions are in parentheses;

All regressions contain dummy variables for years 
Table 9. Budget discipline and fiscal decentralization, 2005-2013, excluding 2009

Dependent variable: Primary balance/revenue

\begin{tabular}{|c|c|c|c|c|}
\hline \multirow[b]{2}{*}{ VARIABLES } & \multicolumn{2}{|c|}{ OLS fixed effects } & \multicolumn{2}{|c|}{ System-GMM } \\
\hline & $(1)$ & $(2)$ & (3) & $(4)$ \\
\hline \multirow[t]{2}{*}{ Dependent variable (t-1) } & & & $0.297 * *$ & $0.327^{* *}$ \\
\hline & & & $(0.138)$ & $(0.142)$ \\
\hline \multirow[t]{2}{*}{ Expenditure decentralization } & $0.589 * * *$ & $0.498 * *$ & $0.800 * *$ & $0.620 *$ \\
\hline & $(0.219)$ & $(0.213)$ & $(0.317)$ & $(0.321)$ \\
\hline \multirow[t]{2}{*}{ Municipal share of all taxes } & $-0.978 * * *$ & & $-1.124 * *$ & \\
\hline & $(0.290)$ & & $(0.544)$ & \\
\hline \multirow{2}{*}{$\begin{array}{l}\text { Municipal share of non-PIT } \\
\text { taxes }\end{array}$} & & $-0.301^{*}$ & & -0.613 \\
\hline & & $(0.170)$ & & $(0.410)$ \\
\hline \multirow[t]{2}{*}{ Municipal share of PIT } & & $-0.494 * * *$ & & $-0.488 *$ \\
\hline & & $(0.155)$ & & $(0.292)$ \\
\hline \multirow[t]{2}{*}{ Transfer dependence } & $-0.611 * * *$ & $-0.526 * * *$ & $-0.848 * * *$ & $-0.905 * * *$ \\
\hline & (0.129) & $(0.117)$ & $(0.318)$ & $(0.245)$ \\
\hline \multirow[t]{2}{*}{ Consolidated debt/Rev (t-1) } & -0.007 & -0.019 & -0.295 & -0.204 \\
\hline & $(0.067)$ & $(0.063)$ & $(0.211)$ & $(0.149)$ \\
\hline \multirow{2}{*}{$\begin{array}{l}\text { Log of Real per capita GRP } \\
(\mathrm{t}-1)\end{array}$} & $-21.172 * *$ & $-14.074 *$ & $-33.983^{*}$ & -12.763 \\
\hline & $(8.772)$ & $(7.841)$ & $(18.251)$ & $(11.262)$ \\
\hline \multirow[t]{2}{*}{ Share of mining in GRP } & 0.011 & 0.124 & 0.450 & 0.443 \\
\hline & $(0.143)$ & $(0.144)$ & $(0.400)$ & $(0.345)$ \\
\hline \multirow[t]{2}{*}{ Log of population } & -37.539 & -30.940 & -0.583 & 2.733 \\
\hline & $(44.533)$ & $(45.157)$ & $(6.530)$ & $(5.474)$ \\
\hline \multirow[t]{2}{*}{ Growth rate of real GRP } & -0.595 & 0.258 & -25.319 & -11.636 \\
\hline & $(12.128)$ & $(12.931)$ & $(27.115)$ & (23.189) \\
\hline \multicolumn{3}{|l|}{ Hansen J p-value } & 0.205 & 0.337 \\
\hline \multicolumn{3}{|l|}{$A R(2) p$-value } & 0.046 & 0.068 \\
\hline R-squared & 0.298 & 0.282 & & \\
\hline Observations & 504 & 504 & 504 & 504 \\
\hline \multicolumn{3}{|l|}{ Number of instruments } & 25 & 27 \\
\hline Number of regions & 72 & 72 & 72 & 72 \\
\hline
\end{tabular}

Notes: Significance levels for coefficient estimates: ${ }^{* *}-1 \%$; ${ }^{* *}-5 \%{ }^{*}-10 \%$;

Robust standard errors adjusted for clustering by regions are in parentheses;

All regressions contain dummy variables for years 
Table 10. Budget discipline and fiscal decentralization, 2010-2013

Dependent variable: Primary balance/revenue

\begin{tabular}{|c|c|c|c|c|}
\hline \multirow[b]{2}{*}{ VARIABLES } & \multicolumn{2}{|c|}{ OLS fixed effects } & \multicolumn{2}{|c|}{ System-GMM } \\
\hline & (1) & (2) & (3) & (4) \\
\hline Dependent variable $(t-1)$ & & & $\begin{array}{c}0.436 * * * \\
(0.154)\end{array}$ & $\begin{array}{c}0.398^{* *} \\
(0.168)\end{array}$ \\
\hline Expenditure decentralization & $\begin{array}{c}1.031^{* * *} \\
(0.313)\end{array}$ & $\begin{array}{c}0.808^{* *} \\
(0.343)\end{array}$ & $\begin{array}{c}0.852^{* *} \\
(0.358)\end{array}$ & $\begin{array}{c}0.825^{* * *} \\
(0.319)\end{array}$ \\
\hline Municipal share of all taxes & $\begin{array}{c}-1.025^{* * *} \\
(0.367)\end{array}$ & & $\begin{array}{l}-0.534 \\
(0.460)\end{array}$ & \\
\hline $\begin{array}{l}\text { Municipal share of non-PIT } \\
\text { taxes }\end{array}$ & & $\begin{array}{l}-0.142 \\
(0.414)\end{array}$ & & $\begin{array}{l}-0.160 \\
(0.323)\end{array}$ \\
\hline Municipal share of PIT & & $\begin{array}{c}-0.738^{* * *} \\
(0.267)\end{array}$ & & $\begin{array}{c}-0.956^{* * *} \\
(0.351)\end{array}$ \\
\hline Transfer dependence & $\begin{array}{c}-0.822 * * * \\
(0.156)\end{array}$ & $\begin{array}{c}-0.705^{* * *} \\
(0.188)\end{array}$ & $\begin{array}{c}-1.181^{* * *} \\
(0.277)\end{array}$ & $\begin{array}{c}-1.033^{* * *} \\
(0.242)\end{array}$ \\
\hline Consolidated debt/Rev (t-1) & $\begin{array}{l}0.262^{*} \\
(0.146)\end{array}$ & $\begin{array}{l}0.272^{*} \\
(0.149)\end{array}$ & $\begin{array}{l}-0.098 \\
(0.154)\end{array}$ & $\begin{array}{l}-0.111 \\
(0.132)\end{array}$ \\
\hline $\begin{array}{l}\text { Log of Real per capita GRP } \\
\text { (t-1) }\end{array}$ & $\begin{array}{c}-8.736 \\
(17.926)\end{array}$ & $\begin{array}{l}-2.979 \\
(16.880)\end{array}$ & $\begin{array}{l}-24.296 \\
(18.053)\end{array}$ & $\begin{array}{r}-24.640^{*} \\
(14.911)\end{array}$ \\
\hline Share of mining in GRP & $\begin{array}{c}0.305 \\
(0.354)\end{array}$ & $\begin{array}{l}0.505 \\
(0.362)\end{array}$ & $\begin{array}{l}0.292 \\
(0.508)\end{array}$ & $\begin{array}{c}0.386 \\
(0.422)\end{array}$ \\
\hline Log of population & $\begin{array}{c}137.548 \\
(141.340)\end{array}$ & $\begin{array}{c}133.060 \\
(136.898)\end{array}$ & $\begin{array}{c}2.223 \\
(7.688)\end{array}$ & $\begin{array}{c}3.625 \\
(6.949)\end{array}$ \\
\hline Growth rate of real GRP & $\begin{array}{c}-6.217 \\
(14.389)\end{array}$ & $\begin{array}{c}1.287 \\
(14.512)\end{array}$ & $\begin{array}{l}-3.333 \\
(28.528)\end{array}$ & $\begin{array}{c}-4.732 \\
(29.907)\end{array}$ \\
\hline Hansen J p-value & & & 0.210 & 0.305 \\
\hline AR(2) p-value & & & 0.018 & 0.033 \\
\hline R-squared & 0.315 & 0.316 & & \\
\hline Observations & 288 & 288 & 288 & 288 \\
\hline Number of instruments & & & 23 & 25 \\
\hline Number of regions & 72 & 72 & 72 & 72 \\
\hline
\end{tabular}

Notes: Significance levels for coefficient estimates: ${ }^{* *}-1 \%{ }^{* *}-5 \%$; ${ }^{*}-10 \%$;

Robust standard errors adjusted for clustering by regions are in parentheses;

All regressions contain dummy variables for years 


\section{APPENDIX}

In this Appendix we present the results of regressions that exclude one or two out of three decentralization measures. We note, however, that given the statistical significance of these measures in our benchmark regressions, particularly expenditure decentralization and transfer dependence, leaving them out of the equations results in misspecification. This is particularly true when we use only one measure at a time. The system-GMM estimates with only one measure of decentralization included generate low p-values for the Hansen J statistic. Although low $p$-value for this statistic if often interpreted as undermining the validity of internal instruments, it can instead reflect other forms of model misspecification, which in our case probably results from the exclusion of the remaining fiscal decentralization measures (see Hall 2005).

Tables A1 and A2 present OLS FE and system-GMM estimates, respectively, that include only one or two main measures of fiscal decentralization at a time. Table A3 shows the estimates where we drop either the municipal share of PIT or municipal share of non-PIT taxes. The share of municipal revenue from all taxes is negative and statistically significant in system-GMM specifications (Table A2). As argued in the paragraph above, these equations are probably misspecified. Also, as Table A3 demonstrates, the statistical significance of municipal revenue share comes predominantly from the municipal share of PIT, the revenue from which can be assigned at the unrestricted discretion of the regional government. Moreover, our main finding of the positive effect of expenditure decentralization holds in all specifications in this Appendix. 
Table A1. Budget discipline and fiscal decentralization regressions excluding one or two measures of decentralization, 2005-2013 (OLS fixed effects)

Dependent variable: primary budget balance/revenue

\begin{tabular}{|c|c|c|c|c|c|c|}
\hline VARIABLES & $(1)$ & $(2)$ & (3) & (4) & $(5)$ & (6) \\
\hline $\begin{array}{l}\text { Expenditure } \\
\text { decentralization }\end{array}$ & $\begin{array}{c}0.598^{* *} \\
(0.255)\end{array}$ & & & $\begin{array}{c}0.632 * * \\
(0.240)\end{array}$ & $\begin{array}{c}0.843^{* * *} \\
(0.286)\end{array}$ & \\
\hline $\begin{array}{l}\text { Municipal share of all } \\
\text { taxes }\end{array}$ & & $\begin{array}{c}0.110 \\
(0.406)\end{array}$ & & $\begin{array}{l}-0.153 \\
(0.389)\end{array}$ & & $\begin{array}{l}-0.193 \\
(0.435)\end{array}$ \\
\hline Transfer dependence & & & $\begin{array}{c}-0.432^{* * *} \\
(0.146)\end{array}$ & & $\begin{array}{c}-0.566 * * * \\
(0.166)\end{array}$ & $\begin{array}{c}-0.458 * * * \\
(0.146)\end{array}$ \\
\hline $\begin{array}{l}\text { Consolidated debt/ } \\
\text { revenue }(\mathrm{t}-1)\end{array}$ & $\begin{array}{c}0.215^{* *} \\
(0.087)\end{array}$ & $\begin{array}{c}0.222 * * \\
(0.092)\end{array}$ & $\begin{array}{c}0.207^{* *} \\
(0.094)\end{array}$ & $\begin{array}{c}0.213^{* *} \\
(0.087)\end{array}$ & $\begin{array}{l}0.193 * * \\
(0.087)\end{array}$ & $\begin{array}{l}0.205^{* *} \\
(0.095)\end{array}$ \\
\hline Log of Real per capita & $-26.263^{*}$ & $-29.487^{*}$ & $-30.427^{*}$ & $-27.049 *$ & -24.925 & $-31.717^{* *}$ \\
\hline $\operatorname{GRP}(\mathrm{t}-1)$ & $(15.745)$ & $(15.645)$ & $(16.180)$ & $(14.798)$ & (16.311) & $(14.864)$ \\
\hline $\begin{array}{l}\text { Share of mining in } \\
\text { GRP }\end{array}$ & 0.521 & $0.553^{*}$ & $0.558^{*}$ & 0.490 & $0.551^{*}$ & 0.521 \\
\hline & $(0.313)$ & $(0.322)$ & $(0.302)$ & $(0.314)$ & $(0.305)$ & $(0.317)$ \\
\hline Log of population & $\begin{array}{c}63.531 \\
(78.974)\end{array}$ & $\begin{array}{c}94.959 \\
(81.432)\end{array}$ & $\begin{array}{l}122.252 \\
(75.797)\end{array}$ & $\begin{array}{c}61.554 \\
(78.105)\end{array}$ & $\begin{array}{c}86.579 \\
(70.890)\end{array}$ & $\begin{array}{l}123.663 \\
(74.862)\end{array}$ \\
\hline $\begin{array}{l}\text { Growth rate of real } \\
\text { GRP }\end{array}$ & $\begin{array}{l}-0.539 \\
(16.722)\end{array}$ & $\begin{array}{c}-0.600 \\
(15.627)\end{array}$ & $\begin{array}{c}0.765 \\
(15.938)\end{array}$ & $\begin{array}{c}-2.382 \\
(15.936)\end{array}$ & $\begin{array}{c}3.637 \\
(17.024)\end{array}$ & $\begin{array}{c}-1.497 \\
(15.582)\end{array}$ \\
\hline R-squared (within) & 0.216 & 0.194 & 0.225 & 0.217 & 0.267 & 0.227 \\
\hline Observations & 360 & 360 & 360 & 360 & 360 & 360 \\
\hline Number of regions & 72 & 72 & 72 & 72 & 72 & 72 \\
\hline
\end{tabular}

Notes: Significance levels for coefficient estimates: ${ }^{* * *}-1 \%$; ${ }^{* *}-5 \%$; $^{*}-10 \%$;

Robust standard errors adjusted for clustering by regions are in parentheses;

All regressions contain dummy variables for years 
Table A2. Budget discipline and fiscal decentralization regressions excluding one or two measures of decentralization, 2009-2013 (system-GMM)

Dependent variable: Primary balance/revenue

\begin{tabular}{|c|c|c|c|c|c|c|}
\hline VARIABLES & (1) & $(2)$ & (3) & (4) & (5) & (6) \\
\hline Dependent variable $(t-1)$ & $\begin{array}{c}0.328 * * * \\
(0.108)\end{array}$ & $\begin{array}{c}0.346^{* * *} \\
(0.128)\end{array}$ & $\begin{array}{c}0.366^{* * *} \\
(0.107)\end{array}$ & $\begin{array}{c}0.324 * * * \\
(0.118)\end{array}$ & $\begin{array}{c}0.330 * * * \\
(0.099)\end{array}$ & $\begin{array}{c}0.361 * * * \\
(0.123)\end{array}$ \\
\hline $\begin{array}{l}\text { Expenditure } \\
\text { decentralization }\end{array}$ & $\begin{array}{c}0.652 * * \\
(0.317)\end{array}$ & & & $\begin{array}{l}0.746 * * \\
(0.303)\end{array}$ & $\begin{array}{l}0.854^{* *} \\
(0.345)\end{array}$ & \\
\hline $\begin{array}{l}\text { Municipal share of all } \\
\text { taxes }\end{array}$ & & $\begin{array}{l}-0.566^{*} \\
(0.309)\end{array}$ & & $\begin{array}{c}-0.560 * * \\
(0.260)\end{array}$ & & $\begin{array}{l}-0.675^{*} \\
(0.389)\end{array}$ \\
\hline Transfer dependence & & & $\begin{array}{c}-0.698 * * * \\
(0.227)\end{array}$ & & $\begin{array}{c}-0.772 * * * \\
(0.243)\end{array}$ & $\begin{array}{c}-0.854 * * * \\
(0.256)\end{array}$ \\
\hline $\begin{array}{l}\text { Consolidated debt/ } \\
\text { revenue }(t-1)\end{array}$ & $\begin{array}{l}-0.036 \\
(0.090)\end{array}$ & $\begin{array}{l}-0.133 \\
(0.084)\end{array}$ & $\begin{array}{l}-0.071 \\
(0.127)\end{array}$ & $\begin{array}{l}-0.099 \\
(0.082)\end{array}$ & $\begin{array}{l}-0.050 \\
(0.132)\end{array}$ & $\begin{array}{l}-0.163 \\
(0.131)\end{array}$ \\
\hline $\begin{array}{l}\text { Log of Real per capita } \\
\text { GRP (t-1) }\end{array}$ & $\begin{array}{c}6.765 \\
(12.926)\end{array}$ & $\begin{array}{c}0.301 \\
(13.834)\end{array}$ & $\begin{array}{l}-1.508 \\
(16.905)\end{array}$ & $\begin{array}{l}-1.684 \\
(9.454)\end{array}$ & $\begin{array}{l}-9.915 \\
(15.717)\end{array}$ & $\begin{array}{l}-16.705 \\
(16.620)\end{array}$ \\
\hline $\begin{array}{l}\text { Share of mining in } \\
\text { GRP }\end{array}$ & $\begin{array}{c}0.008 \\
(0.292)\end{array}$ & $\begin{array}{c}0.123 \\
(0.301)\end{array}$ & $\begin{array}{c}0.314 \\
(0.355)\end{array}$ & $\begin{array}{l}-0.005 \\
(0.284)\end{array}$ & $\begin{array}{c}0.281 \\
(0.356)\end{array}$ & $\begin{array}{c}0.424 \\
(0.379)\end{array}$ \\
\hline Log of population & $\begin{array}{c}2.394 \\
(3.567)\end{array}$ & $\begin{array}{c}2.769 \\
(3.848)\end{array}$ & $\begin{array}{c}4.719 \\
(5.424)\end{array}$ & $\begin{array}{c}1.405 \\
(3.601)\end{array}$ & $\begin{array}{c}3.121 \\
(5.191)\end{array}$ & $\begin{array}{c}4.041 \\
(6.877)\end{array}$ \\
\hline $\begin{array}{l}\text { Growth rate of real } \\
\text { GRP }\end{array}$ & $\begin{array}{c}17.285 \\
(16.132)\end{array}$ & $\begin{array}{c}5.385 \\
(14.354)\end{array}$ & $\begin{array}{c}10.313 \\
(18.741)\end{array}$ & $\begin{array}{c}12.968 \\
(15.047)\end{array}$ & $\begin{array}{c}18.838 \\
(17.892)\end{array}$ & $\begin{array}{c}3.650 \\
(20.003)\end{array}$ \\
\hline Hansen J p-value & 0.073 & 0.038 & 0.064 & 0.034 & 0.215 & 0.668 \\
\hline$A R(2) p$-value & 0.482 & 0.391 & 0.694 & 0.427 & 0.692 & 0.116 \\
\hline Observations & 360 & 360 & 360 & 360 & 360 & 360 \\
\hline Number of instruments & 27 & 27 & 27 & 30 & 30 & 30 \\
\hline Number of regions & 72 & 72 & 72 & 72 & 72 & 72 \\
\hline
\end{tabular}

Notes: Significance levels for coefficient estimates: ${ }^{* *}-1 \%$; ${ }^{*}-5 \%$; ${ }^{*}-10 \%$;

Robust standard errors adjusted for clustering by regions are in parentheses;

All regressions contain dummy variables for years 
Table A3. Budget discipline and fiscal decentralization excluding some or all measures of municipal revenue shares, 2009-2013

Dependent variable: Primary balance/revenue

\begin{tabular}{|c|c|c|c|c|}
\hline \multirow[b]{2}{*}{ VARIABLES } & \multicolumn{2}{|c|}{ OLS fixed effects } & \multicolumn{2}{|c|}{ System-GMM } \\
\hline & (1) & (2) & (3) & (4) \\
\hline Dependent variable (t-1) & & & $\begin{array}{c}0.330 * * * \\
(0.103)\end{array}$ & $\begin{array}{c}0.310 * * * \\
(0.100)\end{array}$ \\
\hline Expenditure & $0.888 * * *$ & $0.866 * * *$ & $0.859 * *$ & $0.883 * * *$ \\
\hline decentralization & $(0.298)$ & $(0.283)$ & $(0.345)$ & $(0.325)$ \\
\hline Municipal share of & -0.109 & & -0.243 & \\
\hline non-PIT taxes & $(0.396)$ & & $(0.289)$ & \\
\hline Municipal share of & & $-0.441 * *$ & & $-0.719 * *$ \\
\hline PIT & & $(0.175)$ & & $(0.327)$ \\
\hline Transfer dependence & $\begin{array}{c}-0.586 * * * \\
(0.174)\end{array}$ & $\begin{array}{c}-0.594 * * * \\
(0.165)\end{array}$ & $\begin{array}{c}-0.816^{* * *} \\
(0.252)\end{array}$ & $\begin{array}{c}-0.790 * * * \\
(0.208)\end{array}$ \\
\hline Consolidated debt/ & $0.191 * *$ & $0.190 * *$ & -0.091 & -0.061 \\
\hline revenue $(t-1)$ & $(0.085)$ & $(0.088)$ & $(0.115)$ & $(0.140)$ \\
\hline Log of Real per capita & -26.002 & -21.981 & -15.986 & -12.648 \\
\hline GRP (t-1) & $(15.739)$ & $(15.493)$ & (11.368) & $(18.596)$ \\
\hline Share of mining in & $0.541^{*}$ & $0.552^{*}$ & 0.342 & 0.339 \\
\hline GRP & $(0.306)$ & $(0.294)$ & $(0.330)$ & $(0.374)$ \\
\hline \multirow[t]{2}{*}{ Log of population } & 82.927 & 96.139 & 2.650 & 4.031 \\
\hline & (70.601) & $(66.686)$ & $(5.586)$ & $(5.655)$ \\
\hline Growth rate of real & 1.839 & 5.001 & 18.008 & 13.053 \\
\hline GRP & $(17.883)$ & $(16.542)$ & $(17.586)$ & (20.102) \\
\hline Hansen J p-value & & & 0.176 & 0.244 \\
\hline $\operatorname{AR}(2) p$-value & & & 0.648 & 0.626 \\
\hline R-squared (within) & 0.268 & 0.276 & & \\
\hline Observations & 360 & 360 & 360 & 360 \\
\hline Number of instruments & & & 33 & 33 \\
\hline Number of regions & 72 & 72 & 72 & 72 \\
\hline
\end{tabular}

Notes: Significance levels for coefficient estimates: $* * *-1 \%$; $* *-5 \%$; ${ }^{*}-10 \%$;

Robust standard errors adjusted for clustering by regions are in parentheses;

All regressions contain dummy variables for years 